\title{
The Media Industry's Structural Transformation in Capital- ism and the Role of the State: Media Economics in the Age of Digital Communications
}

\author{
Manfred Knoche \\ University of Salzburg, Salzburg, Austria, manfred.knoche@sbg.ac.at, \\ http://www.medienoekonomie.at, @MedOek
}

Translation from German: Christian Fuchs and Marisol Sandoval

\begin{abstract}
:
This paper discusses how the capitalist media industry has been structurally transformed in the age of digital communications. It takes an approach that is grounded in the Marxian critique of the political economy of the media. It draws a distinction between media capital, media-oriented capital, media infrastructure capital and media-external capital as the forms of capital in the media industry. The article identifies four capital strategies that media capital tends to use in order to try to maximise profits: a) The substitution of "old" by "new" media technology, b) the introduction of new transmission channels for "old" media products, c) the definition of new property rights for media sectors and networks, d) the reduction of production and transaction costs. The drive to profit maximization is at the heart of the capitalist media industry's structural transformation. This work also discusses the tendency to the universalization of the media system in the digital age and the economic contradictions arising from it. It identifies activity fields of the media industry's structural transformation and shows how the concentration of the capitalist media markets is an essential, contradictory and inherent feature of the capitalist media system and its structural transformation.

The paper identifies six causes of why capital seeks to employ capital strategies that result in the media industry's structural transformation. They include market saturation, overaccumulation, the tendency of the profit rate to fall, capital-concentration, competition pressure, and advertising. The paper finally discusses the role of the state as an agent of capital in general and media capital in particular. It discusses the role of the state in privatisations, neoliberal deregulation, the formation of national competitive states, and various benefits that the state provides for media capital.

This contribution shows that capital and capitalism are the main structural transformers of the media and communications system. For understanding these transformations, we need an approach that is grounded in Marx's critique of the political economy.
\end{abstract}

Keywords: critique of the political economy of the media, capitalism, media industry, structural transformation, the state, media concentration

Acknowledgement: Originally published in German: Knoche, Manfred. 1999. Das Kapital als Strukturwandler der Medienindustrie—und der Staat als sein Agent? Lehrstücke der Medienökonomie im Zeitalter digitaler Kommunikation. In Strukturwandel der Medienwirtschaft im Zeitalter digitaler Kommunikation, edited by Manfred Knoche and Gabriele Siegert, 149-193. München: Verlag Reinhard Fischer.

Translation from German to English with permission by Nomos-Verlag.

\section{Translators' Note}

Manfred Knoche is the most important Marxist political economist of the media in the German-speaking world (see Scheu 2012). He has been a close observer and critical analyst of the media in capitalism over five decades, which resulted in over 100 publications. His academic work started with an analysis of the content of daily newspapers in Germany (Knoche 1968), reflected developments such as the rise of new social movements and neoliberalism, the globalisation of capitalism, and the digitisation of the media, and has most recently included an analysis of the political economy of open access online publishing and its potentials for the decapitalisation of the media and the liberation of the media from capital accumu- 
lation models (see Knoche 2014). He has emphasised the importance of approaching media economics as a Marxist political economy of social communication in order understand, critique and confront $21^{\text {st }}$ century challenges (see Knoche 1999 d).

We have both been colleagues of Manfred Knoche at the University of Salzburg until we left Salzburg in 2010 and during that time had the opportunity for many inspiring discussions with him about contemporary issues in Marxist theory and the critique of the political economy of the media.

In the article we chose to translate form German into English, Manfred Knoche develops a highly anticipatory argument about the media, capitalism and the state in the early $21^{\text {st }}$ century. The paper was published in 1999 and remains absolutely important in 2015. Reading it today shows that many of the tendencies that Knoche described in 1999, partly as mere potentials, have been exacerbated. The article argues that capitalism in general and media capitalism in particular are driven by capitalists' compulsion to accumulate capital and thereby maximise profits. Manfred Knoche analyses the rational behaviour of media capitalists, i.e. how they develop, follow and apply various capital strategies in order to try to maximise profits, which is a structural matter of life-or-death for capital. This drive has brought about structural transformations of the capitalist media industry that Manfred Knoche analyses in detail. This rational behaviour of capital in the form of capital strategies however in a antagonistic manner turns, as he shows, into its opposite, namely irrationalities such as crises, class inequalities, precariousness, and media monopolies and oligopolies that threaten democracy. In capitalism, rationality in a negative dialectic turns into irrationality because capitalism is an irrational system organised in a highly rational manner.

The drive for universal commodification requires the development of the technical and therefore also the communicative productive forces. Knoche shows that the tendency for the creation of a universal media system that is associated with digital media and the Internet is a consequence of capital's drive to accumulate, but at the same time contradicts this drive and creates potentials for non-commercial digital media use that render capitalist media potentially superfluous. Such a universal media system, in which the production, distribution and consumption of information converge and is achieved over one medium, has become partly a reality with the rise of digital media and the Internet. What is today called social media enables the convergence of the production and consumption of information, of work time/leisure time, and of the private sphere and the public sphere.

Within capitalism, these universalisation tendencies of the media advanced by the development of the communicative productive forces remain however, as Manfred Knoche shows, highly antagonistic. There is for example an antagonism between the traditional media industry and the openness industry of Google, Facebook, and other online companies that foster open distribution of content online and make profits with targeted advertising, which questions the profits made by traditional advertising in the printed press and the commodification of cultural content that can easily be digitised and distributed globally online. Global advertising revenue has in the years 2009-2013 increased on average per year by $18.9 \%$ on the Internet, whereas it has decreased on average annually by $1.3 \%$ in newspapers (Ofcom $2014,22)$. The digital universalisation of data and information has resulted in an industry conflict between "old" and "new" media accumulation strategies.

Also new forms of non-commercial media have emerged, as Knoche anticipated in this article from 1999. This becomes for example today evident in the realm of online publishing: Non-commercial, non-profit open access journals such as tripleC question the capitalist publishing industry's capital strategy to use copyrights and sell contents via subscriptions. It has the potential to, as Knoche (2014) calls it, decapitalise the academic publishing system. The enemy does however not sleep: In the meantime, many capitalist open access publishers have emerged and used the very capital strategies that Knoche describes in order to charge authors or their institutions article and book processing charges so that they can accumulate capital. This is especially cynical at times of neoliberal austerity, in which public resources are drained and only rich universities and individuals can pay such fees, which advances academic inequality. 
Knoche in his article argues that capitalism in general and therefore also the capitalist media industry is inherently crisis-prone. The new world economic crisis that started in 2008 has violently shown the importance of this assumption. Especially the traditional publishing industry's crisis has in this context been deepened. Finally, Knoche also stresses the interconnection of capitalist power and state power. Neoliberal austerity measures as reaction to the crisis have once more shown the importance of the state in capitalism. Privatisations of communications, such as of the Post Office in Britain or the (temporary) abolishment of public service broadcasting in Greece by a right-wing government, show the significant role of the state and once again illustrate its tendency to act in the interest of media capital.

Manfred Knoche's work is part of the field of Marxist political economy of the media and communications. It reminds us of the importance to take Marx serious today in order to understand how capitalism shapes, distorts and damages our everyday lives and everyday communication. At the same time capitalism's contradictions have resulted in new hopes for democratic socialism, such as the anti-austerity movements in Greece and Spain or Corbynism in the UK. Digital media's contradiction between digital commodification strategies and the emergence of digital commons is part of this larger contradiction between capitalism and democratic-socialist potentials and struggles.

To study communications and the Internet today without studying capitalism and Marx is outdated, out of tune with everyday reality, and reductionist. Everyone, who considers themselves a critical media and communications scholar, should read Manfred Knoche's article in order to better understand capitalism in the age of digital communications.

\section{Christian Fuchs and Marisol Sandoval. London. October 9, 2015.}

\section{Introduction}

It seems obvious that neither an "invisible hand" (see Abrahamson 1998) of neoliberal ideology of market and competition, nor the sovereign consumers of "economics as a system of belief" (Galbraith 1970), nor system theorists' apolitical space that features autopoietic systems and subsystems, bring about the media industry's structural transformation. Instead, the multitude of empirical evidence showing the national and international movement of capital in the media industry's different sectors (see Röper 1999; Europäisches Medieninstitut 1995; Hagen 1996; Kohlstedt, Seeger and Woldt 1996/1997; Kleinsteuber and Thomaß 1996; Sjurts 1998), indicates the necessity for media and communication studies to take an approach oriented on media economics that focuses on the analysis of capital as the evident main factor in the media industry's structural transformation.

The type and the intensity of contemporary capital movements are not something fundamentally new. Already at the start of the 1990s, the economic press reported: "Acquisition, sale and takeovers, holdings and joint ventures worth billions of dollars characterise this phase, in which large parts of the entire media industry are economically restructured, segmented and rearranged" (Luyken 1990, 621). The integration of telecommunications, the computer industry and the Internet into capitalism as fields for capital ${ }^{1}$ activity created the preconditions for a multitude of further capital movements. This situation has been aggravated by the fact that the media industry, no matter if rightly or wrongly, is considered to be a profitable, future-oriented growth industry.

The necessity of a capital-centred media-economic research approach can also justified from a theoretical perspective: The globally dominant economic and societal order is rightly called capitalism ${ }^{2}$, and the owners of capital have in this system a constitutionally protected

\footnotetext{
${ }^{1}$ Terming the actor that in a commonly accepted manner is often designated as company as "capital" may today be a bit unusual not just in communication studies. In this respect, introductions to Marx's Capital, such as the one by Altvater et al. (1999) are helpful. The book contains an annotated reference list, including works that criticise Marx's critique of the political economy. I do not use capitalism as a political catchword, but as an analytical category for an economy system and a society constituted and functioning in a particular way.

2 One can notice that after what some have termed the "(final) victory over socialism" in 1989, also those apologists, who for ideological-political reasons prefer to use the term "market economy", have started to use the term capitalism with a certain pride.
} 
and almost invulnerable position and freedom of action (see Knoche 1997, 127ff). The farreaching privatisations, i.e. capitalisations ${ }^{3}$, of sectors that were organised as public services or by the state, and the extension of the media industry that has come along with this development, have without a doubt further increased the need for a realistic and fruitful engagement in media and communication studies with capital's laws of movement in general and media-capital's laws of movement in particular. This necessity is especially evident in the still dominant phase of neoliberalism in economic theory and economic policy-making that justifies an almost unrestricted autonomy of capital that accepts "the market" as the only regulator in a "free play of forces".

Another theoretical reason why there should be academic interest in capital movements and their implications in the media industry as particular sector of the capitalist economy is that capitalism has structurally changed. Such transformations have also been discussed from a critical perspective in economics and political science (see for example Altvater 1991; Altvater et al. 1999; Heinrich and Messner 1998; Hirsch 1990; Hirsch 1998; Hirsch and Roth 1986; Jenner 1999; Klages and Strutynski 1997).

This contribution focuses on capital movements and capital strategies in various media sectors. It also analyses implications for the media industry's structural transformation. The foundation of this analysis is the systematic exposition of the media and communications industry that in the course of far-reaching privatisations has expanded. I introduce primarily microeconomic causes and triggers of the identifiable capital strategies. Based on this analysis, I will put the structural transformation of the media industry into a macroeconomic context by relating it to general tendencies of capitalism's structural transformation and to developments in theory that explain these tendencies. I conclude the analysis by pointing out foundations of the relationship of capital and the state. Both play a role in the advancement of the media industry's structural transformation.

\section{The Movement of Capital}

Important legal foundations of the existing capitalist economic system and society, whose premises, norms and laws also apply for media capital, include constitutionally protected economic freedoms such as (see Knoche 1999a, 91):

- The freedom of private ownership of the means of production;

- The free use of private property;

- The freedom of trade;

- The freedom of contract;

- The freedom of competition.

The economic imperative of capitalism and especially of neoliberal "turbo-capitalism" (Fehrmann 1999) is that capital must be in movement. Capital must, as a matter of its own life and death, "work": It must be productive capital in the sense that it is used for the production of surplus-value and thereby yields profits for the capital owner. Unproductive, unprofitable capital is dead capital that not just harms the capital owner, but the total economic system and society.

Media production is from the economic perspective of media companies a means for the socially accepted and legitimised goal of individual companies' profit-maximisation (see Knoche 1999c, 135ff). Capital owners invest capital, often just temporarily, into media products as commodities, in order to rapidly achieve surplus-value and to so convert capital into more capital. Because media corporations and advertisers are interested in a short-term and cheap circulation of their commodities and of their capital (see Holzer 1994, 202-203), media companies strive to "extoll their commodities" and to make use-value promises in order to reduce the time these commodities stay in the circulation sphere and to realise an optimal monetary exchange-value that guarantees the company's profitability and further existence.

\footnotetext{
${ }^{3}$ Capitalisation is the process, by which something is turned into capital.
} 
Profit maximisation is in capitalism in general, and therefore also in the media system, not a cause of societal problems, but rather capital owners' often legitimated, everyday economic imperative: They not just increase their own capital, but thereby also make an important contribution to the functioning of capitalism as economic order and societal system. Capital movements "serve" to sustain the system and are therefore also an indispensable systemic necessity. It is characteristic for the contemporary media industry's structural transformation that not only traditional media capital, but increasingly also capital from other economic sectors is active in it. One can therefore speak of an extended media and communications sector (see Schrape et al. 1996, 124ff) and of an extended media economy (see Kohlstedt, Seeger and Woldt 1996/1997, 168). Based on a distinction among the main areas of capital use in the media industry, I suggest discerning four types of capital (Figure 1):

- $\quad$ First there is media capital in a closer sense. It is active and valorised in the production and distribution of information such as texts, images, sound and audio-visuals in classical media sectors such as press agencies, newspapers, magazines, book publishing, radio, audio, television, film, video and media distribution.

- Second there is media-oriented capital that is only partly valorised in the classical media sectors. It is used in the technical production and distribution of media products and in the production of media technologies. Of particular importance are the paper industry, the printing industry, the machine-building industry, the consumer electronics industry, the chemical industry, broadcast technology, trade, postal services, etc. Also capital that operates in media-oriented advertising, PR, marketing and consumer research belongs to this second category.

- Third there is media capital in the sense of the extended media industry. It can be termed media infrastructure capital and operates in the transmission of information and telecommunications services. It includes capital that operates in the cable-, satellite-, telephone-, computer-, telecommunications-, and online-industry.

- Fourth one can increasingly find media-external capital in the media industry, including the capital of banks, insurances, trade-, construction-, utility-, vehicle construction-, transport- and other businesses. There is a tendency that capital from all economic sectors operates in the media industry. This also includes financial capital that operates in the form of loans and share capital in the media industry.

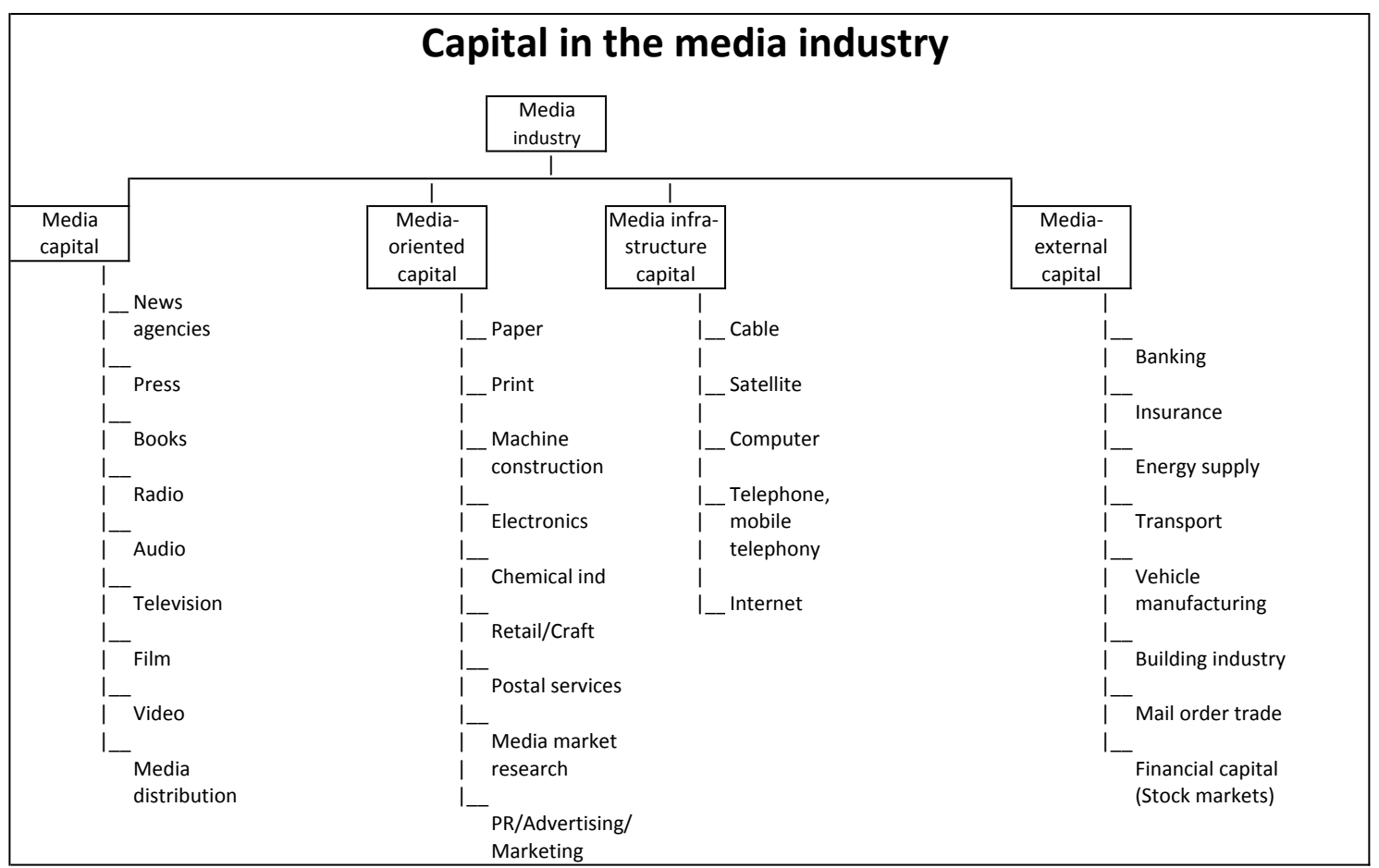


Figure 1: Four types of capital in the media industry

At the start of the 1990s, capital-intensive print media companies engaged in capital movements across media sectors in order to create multimedia corporations. The privatised television sector was the main area of activity (see Luyken 1990, 626ff). The capitals accumulated in the print media sector have stayed influential. But because of the intertwining of the print and the film/video industry, there has been a centralization of multimedia capital (see Röper 1999). In addition, large capital movements originate in the computer industry and mediaexternal capital.

Capital movements across media sectors have also reached the telecommunications industry, digital media, and the Internet's online services. Overall there is a dynamic process of interweaving capital movements across media sectors that has resulted in the extension of the traditional media industry and an extensive interweaving of media sectors (Figure 2). There is a tendency that an integrated "universal" media industry replaces the traditional separation of different media sectors. This universalisation of the media industry takes place at the level of capital and institutions and is likely to affect the whole process of media production and its functions.

\section{The Structural Transformation's Capital Strategies and Activity Fields}

Capital-intensive media corporations are particularly crisis-prone. Therefore, and because at the same time they control sufficient capital and market power in order to successfully survive crises, such capital-intensive companies are usually the media industry's most active structural transformers. Often the result is the devalorisation of capital in competing companies that only hold small amounts of capital. The employed capital strategies largely determine, what kind of structural transformations take place in which of the media industry's sectors at what times. These strategies appear to be offensive and expansive. Their nature is however that they are defensive strategies for overcoming existing economic crises or preventing possible crises. Limiting risks is at the core of capital's strategies (see Bächlin 1975, 95ff; Kiefer 1998, 100ff).

What drives capital? What is the cause of capital's enormous drive for movement that makes it such a central structural transformer of the entire economy and especially the media economy? Given the pressure of saturated markets, the overaccumulation of capital associated with it and the tendency of the profit rate to fall, capital has to seek new, profitable spheres of investment and production-oriented capital valorisation. 


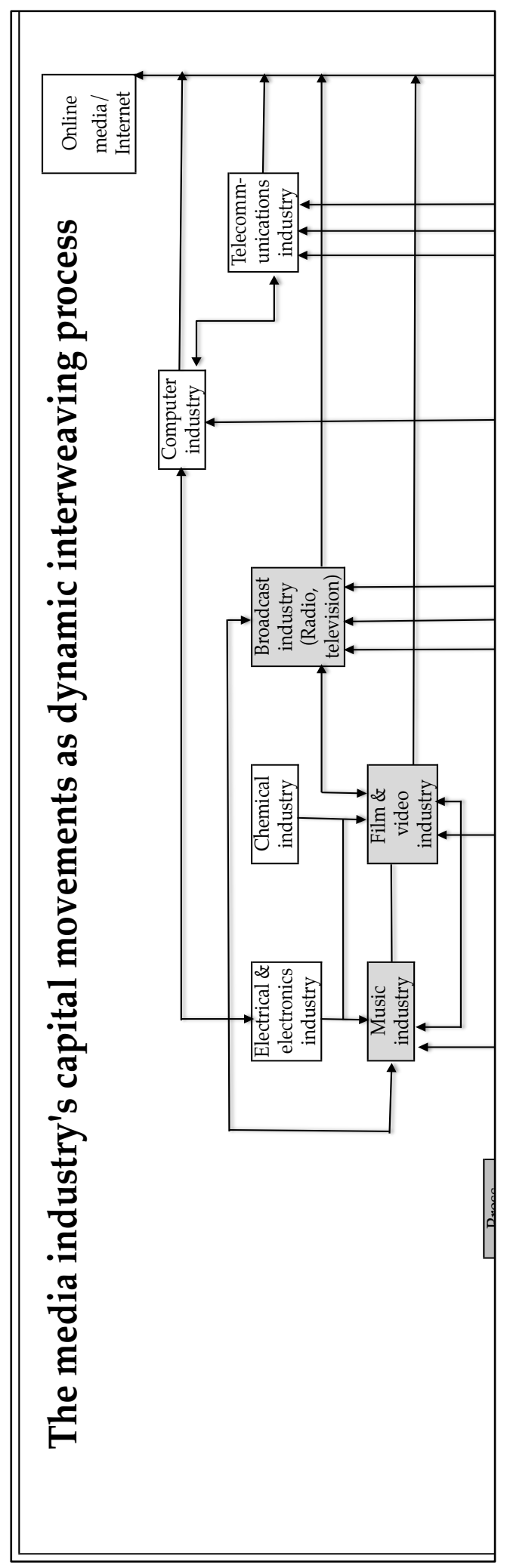

Figure 2: The media industry's capital movements as dynamic interweaving process

Such investments are only worthwhile when there is a relatively secure prospect that the profit rate is higher in the new spheres of production than the one that would be achieved by no longer investing capital in the media industry, but in more profitable economic spheres or by operating as capital invested only in banks and the stock market. Capital is in principle not 
bound in respect to the production of particular products. It is therefore readily moves from one industrial sector to another as soon as a higher profit rate can be yielded or when there is the expectation for such an increase. The media industry tends to be seen as a profitable growth industry, which explains the capital movement from other industries to and the investment of financial capital into the media industry ${ }^{4}$. Coordinated capital strategies that aim at the domination of media markets are the media industry's central interest:

- Coordinated capital strategies operate on the one hand by opening up new spheres for capital investment and new mass markets for new media sectors that can for example be conquered because of privatisations.

- Coordinated capital strategies operate on the other hand by opening up new market segments in traditional media sectors that have largely saturated markets. In such cases, product variations, product diversification as well as digitised media products' multiple valorisation are used as strategies.

In this context the development and the use of old and new media technologies, i.e. technologies used for production, compression, storage, transmission, encryption and reception, are important (see Schrape et al. 1996, 11ff). They can be used for attaining four strategic goals that are foundational for the valorisation of capital and profit maximisation.

\section{The first strategic goal: The substitution of "old" by "new" media technology}

This strategy has the goal to turn products that originally are consumer goods for long-term use into short-term disposable goods ${ }^{5}$ that advance capital's valorisation interests ${ }^{6}$. Capital to a significant extent stimulates the purchase of additional or replacement appliances by manifold product variations (design, features, reception quality, upgrades, modifications of functions and usages, combination with accessory units, etc.) and by a consciously created short product life cycle of "old" media technologies. But only the offer of a "new" reception technology that is not compatible with the old one and in the ideal case comes along with the cessation of the "old" technology's production, puts the necessary pressure on the allegedly sovereign consumers in order to create new mass markets for replacement and additional technologies.

The introduction of new technologies is both an interest of hardware producers (media players and storage media) of content producers. Expressed differently: Such an introduction is an economic necessity for both as soon as the limits of market saturation are reached.

For the content-industry there is the necessity to valorise old contents in a new way over new storage media in old or new markets. This is an economic necessity because on the one hand there is a lack of successfully marketable new content and on the other hand success-

\footnotetext{
${ }^{4}$ A good example is the capital movement towards Internet shares at the end of the 1990s. Important examples were Amazon, eBay, Yahoo!, and AOL. It is part of the everyday business of speculative capital that such developments can result in a "capital crash" ("crash.com"), as the so-called dot.com crisis showed in 1999 (see Kordik 1999).

${ }^{5}$ Press products, especially newspapers, as well as broadcast programmes are in this sense short-lived consumer goods that comparable to food and drinks enable based on subscriptions calculable mass sales as "surrogate purchase" that is the precondition for profitable business, namely the sale of advertisements. The print media industry was for a long time one of the industries yielding the highest profit rates. It is newspaper capital's economic interest to realise this mass of "surrogate purchases" of consumer goods (in addition) in the form of online newspapers that do not have costs for printing, paper and physical distribution (see Knoche 1981).

${ }^{6}$ Remark by the translator (CF): The author in this sentence uses in German the significant distinction between media products' Gebrauch and Verbrauch. This linguistic differentiation cannot be adequately translated to English: Gebrauch means that a (media)commodity remains the users property for an extended period of time, whereas Verbrauch means that a (media)commodity is directly used up in consumption.
} 
ful products ("hits") can only be sold multiple times over new carrier media. Here are examples for such strategies ${ }^{7}$ that are mostly used globally:

- Radio: tube radio, transistor radio, mono radio, VOR radio, stereo radio, combined radio and cassette player, radio with cassette recorder and CD player, hi-fi system, PC and Internet radio, "universal player"

- Television: monochrome television, colour television, stereo television, 16x9 television set, digital set-top-box, PC and Internet-TV, "universal player".

- Audio: record player, tape recorder, cassette tape recorder (mobile: Walkman, car cassette tape player), audio CD player, player for CD-R/CD-RW/SACD/HDCD (mobile: Discman, MP3 player, car CD player), mini disc player, DVD player, digital audio tape recorder (DAT), radio, PC and Internet audio, "universal player".

- Video: optical videodisc, video tape recorder, DVD player, player for DVD-ROM/DVDR/DVD-RAM/DVD+RW; television set, PC and Internet video, "universal player".

- Press: paper, digital publishing, PC desktop and online publishing, "universal player".

- Books: paper, PC and online publishing, e-books and tablets, "universal player".

- Telephone: cable telephone, cordless telephone, fax, combined telephone-fax, videophone, mobile phone, Internet telephone, "universal player".

- Computer: combination of hardware and software: Intel 8088, Intel 80286, Intel 80386, Intel 80486, Intel Pentium, Intel Core, Intel Celeron, Intel 64, Intel Xeon, AMD 29x, AMD $\mathrm{Kx}$, IBM x86, IBM PowerPC, "universal player".

The market for recorded music is an impressive example for the connection of market saturation and the use of the capital strategy "replacement of old by new media technology". Sales data for the German music industry ${ }^{9}$ shows that CD albums were introduced in the 1990s at a time when the market for the sales of vinyl LPs and cassette tapes had reached saturation and that the download of digital music was introduced in the middle of the first decade of the 2000s when the sale of CDs and DVDs had reached saturation.

\section{The second strategic goal: New transmission channels for "old" media products}

On the one hand the cable- and satellite industry, the phone industry, and the industry producing auxiliary devices (equipment for sending and receiving information, satellite dishes, receiver, decoder, set-top-boxes, etc.) are interested in this strategy in order to open up new sales markets that help to replace old by new transmission technologies. On the other hand also media content companies are interested in this strategy because it allows them to expand the market for the sale of media products that are transmitted over different channels. Here are some examples:

\footnotetext{
${ }^{7}$ I discuss, without the claim for completeness, only technical innovations in the realms of storage media and reception equipment that because of fundamental novelties that are not compatible with previous media technologies compel consumers more or less to buy new receivers and appropriate storage media. I do not discuss the multitude of variations of equipment, storage media and auxiliary devices that are also economically important.

${ }^{8}$ A "universal player" does not-yet exist, could however be technically realised without problems. It is a future vision that at the moment is only economically desirable for parts of media capital. Both digitisation and the Internet have been steps towards the introduction of a universal player. It is however an illusion to think that these tendencies will result in less "compulsion" for consumers to buy replacement units and in cost-savings. Media capital will rather only be able to satisfy its valorisation interests by technically replacing or complementing the universal player when market saturation sets in so that consumers are constantly stimulated to make "replacement purchases" or additional purchases. An impressive example is the frequent introduction of costly new hardware and software versions in the realm of computing (Rojas 1998).

${ }^{9}$ Bundesverband Musikindustrie:

http://www.musikindustrie.de/fileadmin/piclib/statistik/branchendaten/jahreswirtschaftsbericht2014/download/Abb10b-Absatzentwicklungderdeutschen_300dpi (accessed on October 7, 2015).
} 
- Press: broadband cable, fibre optic cable, broadband-ISDN, Internet, "universal network" ${ }^{10}$.

- Broadcasting: terrestrial broadcast network, broadband cable, satellite transmission, fibre optic cable, broadband-ISDN, Internet, "universal network".

- Telephone and data transmission: analogue narrowband network, digital network (ISDN), broadband ISDN, Internet, mobile phone, "universal network".

\section{The third strategic goal: New property rights for media sectors and networks}

The opening of spheres for capital investment in the realm of "new" media sectors and networks has become an important capitalist strategy in the media industry. It involves the formation of property rights for media products and rights of use for networks, which implies their commercialization. Examples are digital pay TV, online services, and networks that have been commercialized (see Schrape et al. 1996, 43ff). This strategy includes the commercialization of media sectors that have previously been non-commercial as important aspect of the media industry's structural transformation ${ }^{11}$.

Because of its fundamental importance to the media industry and the media system's further development, the capitalisation and "conquer" of digital television and the Internet play a key role in this context. In the course of the digitisation of media technology and the associated possibilities for the cost-saving non-physical design of products and the non-physical distribution ${ }^{12}$ of media products that earlier could only be distributed in physical form over physical carrier media, property rights on media (content) products and on the technical access possibilities for a mass audience play a key role. It is therefore only consequent that corporations such as Bertelsmann, Murdoch's News Corp, Berlusconi's Mediaset, the RTL Group, or Canal+ have used this third type of strategy in order to obtain property rights access possibilities. They also make use of capital investment in shareholding companies, cooperation or strategic partnerships to attain these goals. Examples include:

- Television: analogue (pay per channel), digital (pay per view, video near on demand, video on demand).

- Press: Internet (online-newspapers, online-magazines, electronic paper distributed on ebook readers).

- Books: CD-ROM, Internet (book on demand, e-book), e-books distributed on e-book readers.

- Recorded music: Internet (audio/music on demand, iTunes, Spotify).

- Video: Internet (video on demand), streaming.

- Internet access: Internet service providers, navigation systems, online services.

- Networks: terrestrial broadcast networks, analogue narrow band networks, digital telephone networks (ISDN), cellular phone networks, broadband cable networks, satellite networks, fibre optic cable, B-ISDN with ATM (broadband-ISDN with asynchronous mode of transfer), "universal network".

Media technologies and media products that are goods for multiple use (as for example the book, sound carriers, the cassette recorder, the radio set, video, the video recorder, the television set, or the CD-ROM) have in contrast to media goods that consumers tend use just once (such as the newspaper, the magazine, radio and television programmes) the economic disadvantage for media corporations that besides the tendency for media technology's

\footnotetext{
${ }^{10}$ The "universal network" is a strategic tendency that corresponds to the "universal player". Together they constitute the main tendency in the media industry's structural transformation.

${ }^{11}$ An example is the privatisation of the German broadcasting sector (radio and television) in the middle of the 1980 s.

${ }^{12}$ In the case of the non-physical distribution of products, consumers directly cover the considerable distribution costs (for network or telephone charges and end devices) that media companies (partly) tend to "pre-finance" in the case of traditional means of distribution.
} 
longevity and the associated tendency for market saturation, there is the technical possibility for everyone to copy and duplicate media contents free of charge, which can result in decreasing profits.

Media companies are confronted with the general threat that they cannot increase the capital they invest into production to the desired or expected degree. They can even lose part of this capital. This problem has been exacerbated by the improvement of digital storage-, data compression-, transmission-, copy- and playback-technologies as well as by the Internet's technical possibilities. The global music industry is worried by the thereby existing possibilities for non-physical distribution (free of charge) of music over the Internet (supported by compression formats such as MP3). What the industry calls from its standpoint "pirate copies" or "piracy" can reduce these companies' profitability to a significant degree ${ }^{13}$ (see Hertz 1999).

That corporations secure property rights on the products that they pre-finance with their capital has always been a necessity for their continued existence. They have in co-operation with state power developed "intellectual property rights"14 as key instruments for copy and duplication protection that outlaw the "illicit" reproduction, i.e. reproduction without companies' agreement or without payments to them. Book and press publishers have secured themselves monetary payments ("levies") from libraries and copy-shops in order to yield profits from such copyrights. Such levies partly also benefit the creators (in publishing there is for example in Germany the collecting society WORT). There is also an organised levy and control system for the reproduction and play of audio-recordings, videos and movies (in Germany this is the task of the GEMA - Gesellschaft für musikalische Aufführungs- und mechanische Vervielfältigungsrechte [Society for musical performing and mechanical reproduction rights]). It secures the intellectual property rights and copyrights that media corporations have secured for themselves.

Because property rights are in the media industry even with penalties hard to enforce, media corporations have developed and used technical means for copy protection. Also the computer industry uses such technologies in order to prevent the copying of software. The music industry has undertaken great efforts to establish technical copy protection in addition to legal copyright protection. For doing so, it makes uses of new technologies' advantages. Encryption and encoding technologies that can be used in manifold ways in the realm of digitised media products guarantee an almost perfect copy protection.

The industry uses for example computer-readable identification numbers on CDs, digital watermarks embedded into music or films, or registered private codes or customer numbers. The entertainment industry, the telecommunications industry, and the computer industry collaborate in the development of such protection systems. Already in 1996, 100 members states of the World Intellectual Property Organization (WIPO) agreed on legal protections against the bypassing of technical copy protection and the legal ban of technologies that allow such bypassing (see Hertz 1999, 68f). They thereby have supported the music and film industries' economic interests. Publishers have undertaken similar measures in the realm of digital book publishing (see Rink 1999).

\section{The fourth strategic goal: The reduction of production and transaction costs: Towards the media system's universalisation?}

\footnotetext{
${ }^{13}$ The music industry that is dominated by the global corporations Universal (part of Vivendi), BMG, Sony Music, and Warner Music Group has developed a counter-strategy, in which it combines panic and panic-mongering.

${ }^{14}$ Property rights nominally protect the intellectual rights of authors, writers, artists, composers, etc. (and their heirs!). Capital discusses the protection of copyrights under these premises. They have therefore succeeded without problems in defining these rights for the protection of their material property, although they are not the intellectual creators and they in reality are only interested in the protection of their economic property, i.e. their capital. Their reference to copyrights is legally legitimated by the fact that creators transfer their rights with contracts to media corporations. In academia, this is often done at zero costs for the corporations. Sometimes authors even have to pay publishers (!) in order to get published. Consequently the media corporations only proclaim copyrights and not authorship rights.
} 
By using new media technologies, media corporations can achieve their fundamental and strategic goal of reducing production and transaction costs in manifold and partly radically new ways. Large media capitals have partly realised the technically possible strategies and have thereby driven forward the media industry's structural transformation. The various planned and applied strategies result in a stepwise structural transformation in the course of which the media industry can be developed into the direction of a "universal medium"15 in respect to technologies, products and economic institutions. A universal medium also implies the existence of a universal network and a universal receiving set so that media content reaches consumers.

It is difficult to forecast the development and duration of the long-term universalisation process and how it will unfold in various media sectors at the level of media-production, distribution and -consumption. The universalisation of the media can call forth media capitals' resistance if they perceive the partial universalisation of the media system as a threat to their existence. This is especially the case for companies engaged in the traditional distribution of physical media products. The internally contradictory interests of the most powerful and market-dominating capitalist media corporations determine the degree, sequence and speed of the media system's universalisation. They too are at least for the foreseeable future only partly interested in media universalisation because complementary production, distribution and consumption serves their interests in capital's valorisation better than substitution ${ }^{16}$.

The existing separation into different media sectors that focus on textual/visual communication (press, books), audio communication (radio, audio-recording), audio-visual communication (television, video, film), voice and data communication (telephone, Internet) has just like the separation between different means of transmission, the separation between different storage media, and the separation between different receiving sets, thus far remained economically desired and used in the interest of capital's valorisation, although there are technical possibilities for overcoming this separation (see Ouaj et al. 1998, 74).

The realisation of a consequent universalisation-strategy (aiming at unified digital and electronic media production for all forms of communication, a unified digital and electronic transmission channel that uses the possibilities posed by interactivity, as for example on the Internet, in fibre optic networks, on broadband-ISDN or on the basis of the Asynchronous Transfer Mode ${ }^{17}$ [ATM], as well as a unified digital electronic receiving set such as the PC or networked television) would have consequences that could threaten capital. The universalisation of the media system and even the partial integration of different media sectors as its preliminary stage would render capital investments in several media sectors largely functionless and therefore dispensable.

It is not the case, as however media corporations and many scientists often foreground, that consumers' lack of acceptance and their lack of willingness to pay (that certainly exists in the medium-term) is decisive for the universalisation of the media system's "nonrealisability". The economic "convergence obstacle" (Garnham 1995, 75) is rather opposed

\footnotetext{
15 The terms "universal medium" and "universalisation" of the media go beyond the meanings of the categories multimedia, convergence and "mediamatics" (Latzer 1997). They imply the total dissolution of the separation of different communications as autonomous media and a creation of their unity at the level of technology, products, institutions and the economy.

${ }^{16}$ An example: For press and book publishers only a complementary usage of the Internet can be an economically viable company goal as long as they cannot reach a mass market via the Internet. Because of the print media's highly visible price differences (high variable capital costs for paper, printing and distribution), this industry without a doubt has in principle an economic interest in the substitutive, non-physical production and distribution of press products over a universal network and by a universal receiving set. A new situation would emerge if for example Internet TV became a dominant mass phenomenon among the consumers and the press got access to it. In such a case, a gradual strategic transition into the direction of the complete substitution of (physical) print media products could become possible.

${ }^{17}$ International telecommunications companies decided already in 1988 to develop ATM as transmission principle that is independent of specific services. According to Schrape et al. (1996, 24), "this assured the electronics industry that it here would find an enormous market potential in the future. As a consequence, extensive research and development capacities have been deployed in order to create ATM products ready for the market".
} 
by media capitals' elementary interest in media products' multiple valorisation and their interest in the preservation of possibilities for capital's valorisation-possibilities in existing production and distribution sectors.

Past examples show that media corporations have the potential to "create" the acceptance of "new" media by fostering costly forms of marketing and advertising. If necessary they can do so "by force" and make exclusive offers of media products or non-compatible media technologies. This could be particularly successfully in the case of a universalisation of the media system because the latter could bring about economic and communicative advantages for consumers (fewer financial expenditures for different media products and technologies that overlap at the content level, larger satisfaction of communicative needs, etc.).

Such a universalisation is an economic threat to the affected capitals. They could however escape it by moving into other economic realms. One can however expect that the devaluation of capital would especially affect small retailers in the distribution sector. Employees affected by capital's outsourcing and devaluation have substantially fewer possibilities to transfer their only "capital", namely their labour-power, into other "investment spheres". This circumstance illustrates capitalism's fundamental contradiction that it can be in the employees' existential economic interest that a functionally dispensable or even hazardous form of valorising capital is kept up, although the workers as consumers or citizens could, as in the case of the media system's universalisation, have an economic and/or an ideational benefit from the omission of media products' separated ("expendable") manufacturing and distribution.

This circumstance can be very well demonstrated by a comparison of the multitude of existing separated stages of production and distribution and their technically possible and for the respective beneficiaries economically attractive omission in the course of the digital universalisation process (Figure 3$)^{18}$ :

1. Production: The dispensability/omission of separate corporate divisions for the production from specific forms of communication, especially "bounded" types of communication such as textual, visual or audio communication.

2. Storage/Reproduction: Dispensability/omission of corporate divisions for the manufacturing of carrier media/storage media, sound carriers, video carriers; of specialised corporations that print media, of paper used in printing media, bookbinding, pressing and copying of sound carriers and videos.

3. Distribution/Transmission: Dispensability/omission of corporate divisions for the distribution of print media (press/book-retail, postal delivery, publisher-owned distribution); of sound carriers, videos and movies (retail, video stores, cinemas); of companies that produce separate networks (narrow band- and broadband-cable networks, etc.).

4. Consumption: Dispensability/omission of corporate divisions for the manufacturing of separate receiving sets for sound and audio-visual media.

This technically and economically in no respect utopian universal "convergence" of the media system would primarily benefit only parts of media capital, which would at the same time be turned into "offenders": They would benefit at the expense of other parts of media capital, which would become the structural transformation's "victims". For most media capitals, such strategies that are technically possible and that at the level of the total economy and corporate policy "rationale" partly also benefit consumers' economic interest, are not feasible goals.

\footnotetext{
${ }^{18}$ Figure 3 is a further development of a model of production stages that Aufermann, Lange and Zerdick (1972, 250ff) developed for the press and Aufermann, Knoche, Lange and Zerdick (1976, 84ff) for several media sectors. Seufert $(1997,259 \mathrm{ff})$ uses a similar approach (however for the delimitation of media markets).
} 


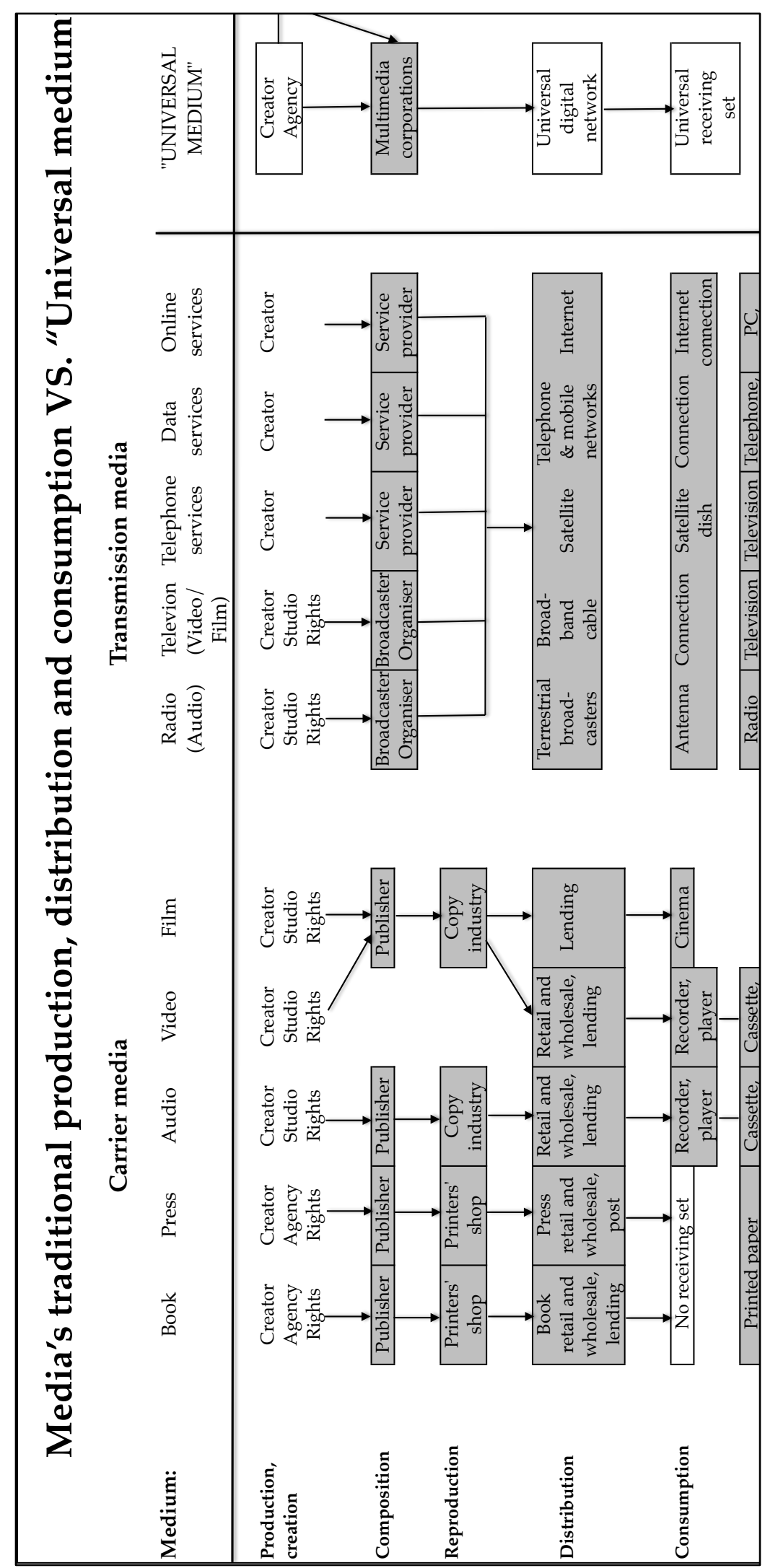

Figure 3: Media's traditional production, distribution and consumption vs. "universal medium"

To the contrary: The realisation of a universal media system and technology would on the one hand threaten certain companies' quasi-monopoly positions in specific traditional media sectors. It would on the other hand existentially endanger capital's valorisation in the media- 
oriented economy as well as in a multitude of the media economy's traditional subareas. Even large parts of the consumer electronics industry would be affected, at least in the part that produces in principle "unnecessary" storage media and receiving sets.

But also the potential economic beneficiaries of the media industry's universalisation, i.e. the dominant multimedia corporations as well as big corporations in the electronics industry, the information technology industry, the telecommunications industry and the media infrastructure industry, tend to only have a limited economic interest in a fast and extensive universalisation. They tend to consider the centralisation of capital in the media industry as not advanced enough. The universalisation of the media system would undermine these companies' basis for the already discussed multiple possibilities for the multiple valorisation of media technologies and media products in various media markets.

The organised and controlled multiple valorisation of media (content) products is because of the non-physical character of these products relatively cost-efficient (see Kiefer 1998, 110111). It has therefore traditionally widely advanced. It further advances in the course of the media industry's structural transformation based on digitised products (see Luyken 1990, $634 \mathrm{ff}$, for a discussion of the television market's structural transformation). One can observe that the traditional "windowing" of media products, i.e. the strictly time-delayed multiple valorisation of movies over diverse distribution channels such as the cinema, video, pay-TV and freely accessible television, tends to be complemented by "versioning", i.e. the distribution of media products' various versions and in the context of diverse usage aspects (see European Communication Council Report 1999, 54, 186ff).

It is a basic element of the capitalist economy and capital owners' interest that technical progress only takes place piecemeal in successive development cycles and is only made available bit by bit according to the specific valorisation interests of the in most cases largely concentrated capital that dominates the market and its specific production- and salesstrategies in particular phases ${ }^{19}$. This means for example at a concrete level that already developed technologies are retained, i.e. not made available for use and kept from the market, until the market for the "old" technology becomes saturated so that the use of "new" technologies becomes necessary and economically profitable. Well-known examples are the conscious "retention" of the production of colour television sets and CDs.

The media industry also provides many examples for the acquisition of patents in order to use them as "blocking patents" against unwanted products (see Jürgens 1976, 21). Conversely "new" technologies are often only developed, produced and marketed in a certain phase in an anticipatory manner in order to open up new markets that are economically necessary at these points of time. The development of certain technologies is deliberately stalled when it is unprofitable from the logic of valorisation and competition or is considered to be "premature".

Capital to a large extent determines technologies' development and (commercial) use. It in this context makes use of large financial subsidies provided by the state for long-term large-scale research and development projects. The development of the Internet is in this respect somewhat atypical because in its early phase it advanced without capital's direct influence. Established traditional media corporations have at first seen the Internet and the World Wide Web (WWW) as annoyance or even a "threat". With the Internet's rising importance, they have tried to develop strategies of how to use the WWW for sales, advertising, marketing, promotion and public relations.

On the one hand the Internet opens up possibilities that are in principle "detrimental to the system" and enable non-commercial media production. On the other hand it enables the direct and interactive communication between recipients and authors, artists, news agencies,

\footnotetext{
${ }^{19}$ An illustrative example is that in Germany the coalition government of the Conservatives (CDU/CSU) and the Liberals (FDP) in the early 1980s pushed the use of copper coaxial cable that was hardly innovative and economically unprofitable. It did so in the interest of the private print media and the advertising industry that both were interested in the fast development of the commercial television market. Also the cable industry had a natural interest in the commercial valorisation of the copper coaxial cables that it had stored for some time although it at this point of time had already technically developed fibre optic cables. The intention was to first commercially valorise cooper coaxial cable and then in a second round fibre optic cable.
} 
the economy, public administration, civil society organisations and institutions. Existing media as economic institutions (corporations) thereby become in principle unnecessary.

Established traditional media corporations also consider the Internet a threat to their economic interests because it opens up the following possibilities:

- Intellectual creators can economically valorise their media products directly and without economic dependence on established media corporations.

- The same is true for organisations such as news agencies and information services,

- and also holds for the advertising industry, which has the interest to individualise, personalise and target advertising.

- Likewise all political, cultural, academic and social institutions and organisation can distribute their information and opinions ${ }^{20}$ directly and independent of established media corporations.

So media capital takes initiatives to economise, commodify, and commercialise the Internet and turn it into an instrument for its interests so that it becomes subsumed under the control of the dominant capitalist economic and media system. Established media corporations' complementary use of the Internet as distribution channel in various media sectors is part of this strategy.

Media capital for example engaged in online services of news agencies, newspapers, magazines, radio and television that at first were largely offered without costs to the consumers, but have in the meantime to a certain degree become subscription services ${ }^{21}$. It also invests in Internet shopping in order to sell books, CDs and movies.

Capital that is invested in the media industry advances a fundamental and extensive structural transformation of the media industry in a multitude of activity fields (Figure 4). Media corporations' structures and organisations are on the one hand fundamentally transformed by capital concentration and strategic alliances between already highly concentrated single capitals. On the other hand these developments have also structurally transformed the production and distribution of the media and the modes of production. These developments have had far-reaching consequences for media and cultural labour, education and the job market (see Altmeppen 1999). Because of the transformations of media production that the development of media technology has brought about, also media market research and media marketing face new challenges such as online research and online marketing.

\footnotetext{
${ }^{20}$ I do not want to create utopian illusions, but rather want to point out the possibilities that exist in principle. Intellectual creators face for example the problem of how to gain the visibility and the attention of the mass audience. The world of social media, where some well-known celebrities and companies have high visibility, is a good example for the stratified attention economy.

${ }^{21}$ Examples are the online versions of Rupert Murdoch's newspapers, such as The Times, The Sun, The Financial Times, The Wall Street Journal, or The Australian that were first offered online without payment and later introduced subscription fees.
} 


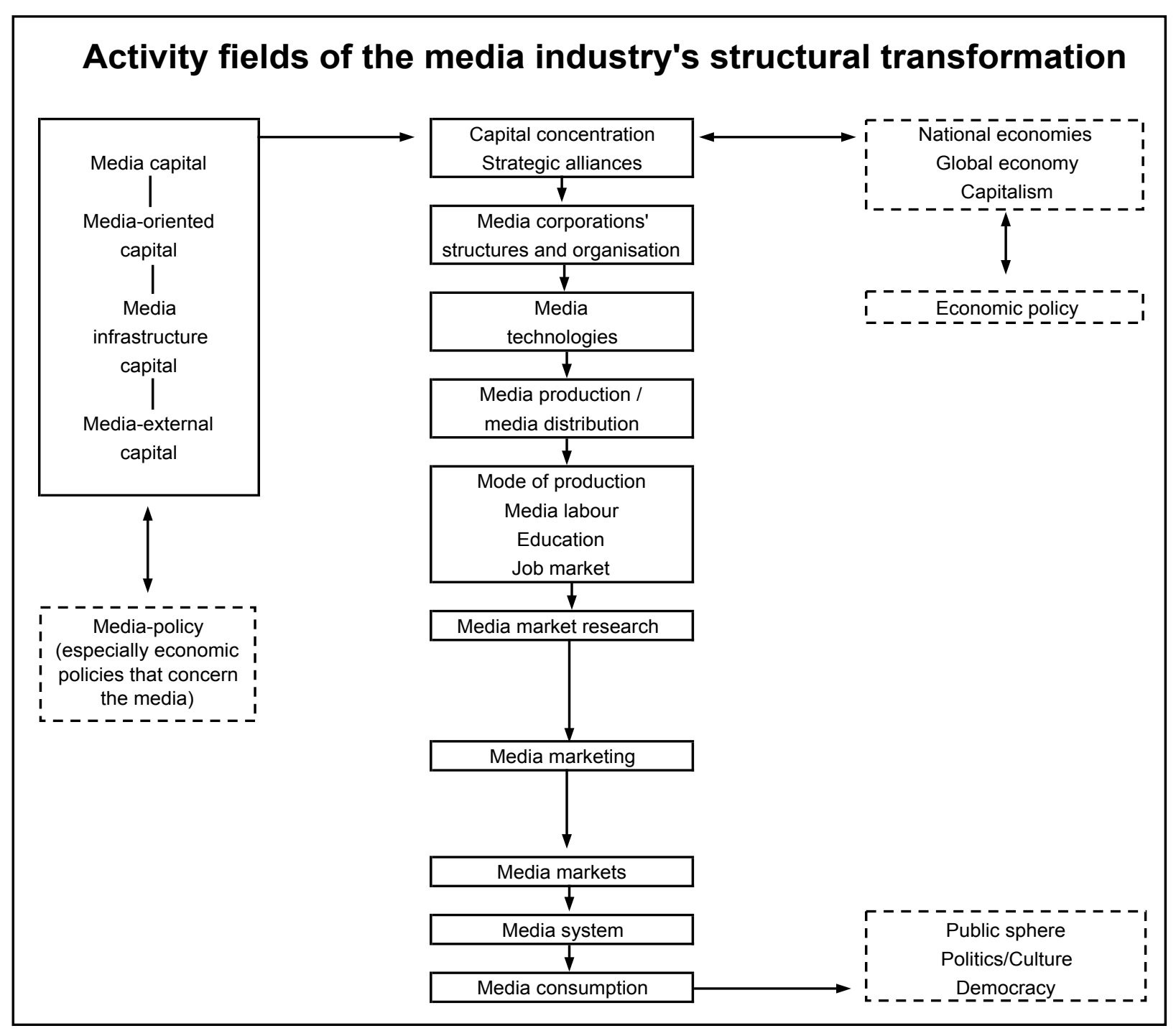

Figure 4: Activity fields of the media industry's structural transformation

The key structurally relevant activity field for capital strategies is the influence that media markets' and the media system's restructuring have on media consumption. The structural transformation advanced in single activity fields has impacts that go far beyond the media industry: Just like in the past, the media economy's structural transformation also today largely influences media politics and media policy-making. Media policy-makers usually either only react ex-post to capital strategies' "accomplished facts" by legitimatising these strategies at the political and legal level (see Knoche 1996b) or promote and stimulate structural transformations in the interest of capital (see Knoche 1996a). It is not an exaggeration to say that the media industry's structural transformation because of its fundamental importance influences the development of national economies and in the context of internationalisation- and globalisation-tendencies also the world economy. The media industry's structural transformation impacts global capitalism's development. One must also take into account the extent to which the media industry's structural transformation has transformed the public spheres' structures in the political and cultural systems and thereby also democracies' development (see Knoche 1999b). 


\section{Media Capital's Centralisation as the Means and Expression of the Media In- dustry's Structural Transformation}

Concentration-supporting capital movements such as acquisitions, mergers, capital interlocking, cross-ownership, joint ventures, co-operation, strategic alliances, business webs, etc. are central means for achieving the identified strategic goals. An associated tendency is media capital's and media markets' internationalisation, which also advances capital concentration. Often measures resulting in capital concentration and co-operations that tend to have the same result are often legitimated with the argument that concentration and co-operation support the maintenance or the creation of international competitiveness. Such a focus on concentration contradicts capital's generally propagated principle of competition.

Examples for the unified use of almost all discussed capital strategies are the strategies of large media corporations such as Bertelsmann, Axel Springer, Murdoch' News Corporation, Berlusconi's Mediaset, Time Warner, The Walt Disney Company, usw. (see Artopé and Zerdick 1995). Their strategies focus on multimedia, are international and result in capital concentration (see Hagen 1995; Sjurts 1998).

In addition to strategies oriented on pay TV and the Internet global media corporations routinely use also strategies that advance the accumulation and centralisation of capital. An example: In the 1990s, the Bertelsmann subsidiary Ufa Film \& Fernseh GmbH was merged with the Luxembourg-based company CLT, which resulted in the creation of the Bertelsmann AG that achieved a strong position in the privatised German television market and became a competitor in the international broadcasting market (see Röper 1997, 226). Bertelsmann paid 1.5 billion Deutschmark ( $€ 750$ million) for a $50 \%$ in CLT. Bertelsmann has also engaged in the acquisition of publishing houses ${ }^{22}$.

Penguin Random House is an example of capital interlocking, co-operation and a strategic alliance (for examples from the telecommunications industry see Schumacher 1997). Such strategies aim at increasing market power regardless of dominant ideologies of competition in politics and academia. The goal is the elimination or at least the limitation of competition. It is also common that there are changing partnerships and co-operations with companies, to which a corporation stands in competitive relations in other economic sectors.

One can observe an international "inflation by strategic alliances" (Schrape et al. 1996, 55), whose goal it is to dominate distribution channels and technical means of transmission by establishing co-operation among dominant programme and content producers, quasimonopolistic operators of networks or satellites, and media technology producers. The domination of new media markets becomes thereby possible. Strategic alliances are rightly considered to be an effective means for creating access barriers to new markets based on the co-operation of highly concentrated industrial sectors. The result is that specific companies reduce their investment risks by co-operating with others. Strategic alliances advance the media industry's internationalisation. They contribute to dissolution of traditional industry structures and to the formation of monopolies, oligopolies and uncontrollable market power (see Schrape et al. 1996, 61). The vertical integration of industries plays an important role in this context.

Some media corporations also see initial public offerings as an appropriate means for raising capital. An example: The initial public offering of the German television channel Pro Sieben in 1998 raised around 1.1 billion Deutschmark $(€ 550 \text { million })^{23}$. The introduction of share capital results in a kind of expropriation of small business owners because large capital funds, banks or venture capital firms tend to become major shareholders and to obtain power over capital, the means of production and the production process (see Huffschmid $1970,94 \mathrm{ff})$

\footnotetext{
22 Bertelsman for example in 2013 merged its publishing company Random House with Person plc's Penguin Group, which resulted in the creation of Penguin Random House that is jointly owned by Bertelsmann and Pearson.

(Note from the translators)

${ }^{23}$ Der Spiegel, No. 52/1998, 21.12.1998, page 100.
} 
Figure 5 summarises the economic interlocking between media sectors in Germany (see also Meier and Trappel 1998, 52ff, for a discussion of the European level). The seven largest media corporations have invested their capital in different media sectors. Many of the German media corporations have been active for a long time in publishing (newspapers, magazines, advertising journals, books) and expanded first into the radio and television sectors and then also into the online economy. The publishing sector is Germany's media sector that is most internationalised. Bertelsmann and Holtzbrinck are the two German media corporations that have the most advanced activity in a diversity of media sectors.

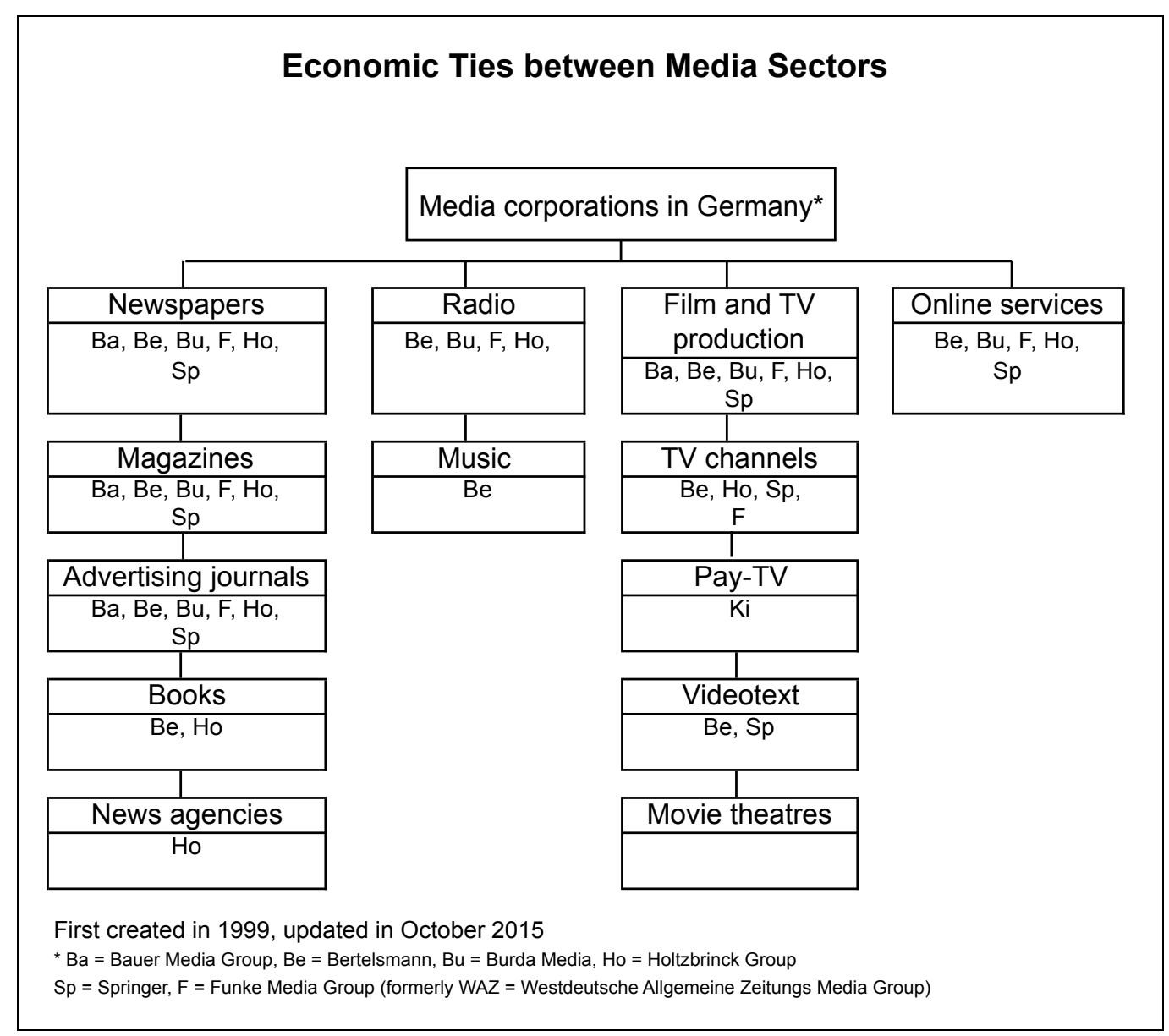

Figure 5: Economic ties between media sectors

\section{Capital Strategies' Economic Causes}

Corresponding to observable crisis symptoms, one can identify major causes and triggers for capital strategies in the media industry. Figure 6 gives an overview of such causes and tendencies that advance the media industry's structural transformation. There are six predominant causes that permanently move capital in the form of lawful cyclically occurring crisis symptoms or crisis-anxieties. Such crisis tendencies and causes existed also long before information and communication technologies' digitisation:

1. Traditional media sectors' high degree of market saturation that only opens up the possibility for corporations with large capital assets to create additional product markets by market segmentation and product diversification.

2. The overaccumulation of capital, i.e. too much capital is employed in relation to low productivity so that parts of the capital lie fallow and become unprofitable. 
3. The tendency of the profit rate to fall is caused by the development that in the course of the production process' technical and scientific progress the share of constant capital (technical means of production) increases in relation to the share of variable capital (labour-power) to such a degree that results in a decrease of the rate of surplus-value that is predominantly determined by labour's production of surplus-value.

4. Due to high levels of capital- and market-concentration only corporations with high levels of capital assets can achieve their goal of increasing profits or avoid the devaluation or destruction of capital.

5. Other causes result in increased rivalry between concentrated capitals, which forces them to engage in further co-operation and to further advance capital concentration.

6. The advertising industry exerts pressures to increase advertising potentials, which compels media capital to diversify its products and to create new advertising-based media.

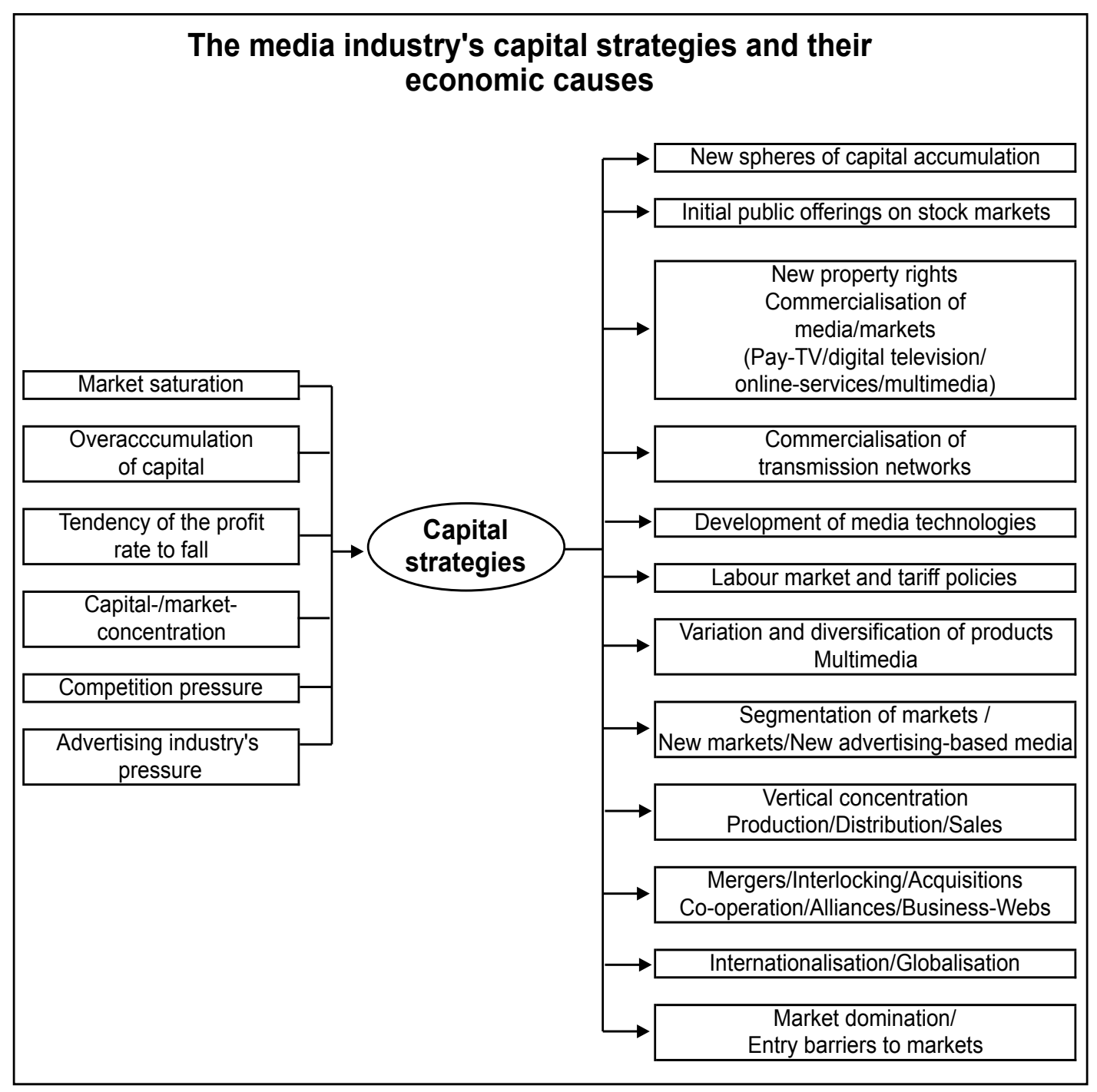

Figure 6: The media industry's capital strategies and their economic causes

Capital regularly uses a multitude of capital strategies (see Figure 6) to combat and try to overcome capital-valorisation's lawful crises. It aims to maximise profits by dominating markets and erecting entry barriers to markets with the help of capital strategies. Of particular importance are strategies that extend spheres of capital investment, raise capital (initial public offering, borrowing/loans), establish new property rights (pay TV, digital television, multimedia, online services) and commercialise not-yet privatised media sectors. The strategic development of media technologies, product variations and diversification, and the introduc- 
tion of multimedia aspects of products play an important role in this context and enable the opening-up of new media markets and new market segments. As already mentioned, especially diverse concentration measures form a crucial strategy basis for the use of strategies that bring about market domination in the context of "competition strategies" (see Hagen $1995,142 \mathrm{ff})$.

\section{The Media Industry in Capitalism: The State as Capital's agent? ${ }^{24}$}

\subsection{State-led privatisation policy}

The media industry's structural transformation that has been outlined in the previous sections can be explained form a theoretical perspective by considering the structural transformation of capitalism in general as it is being promoted by capital and the state. I will in this section focus on one particular aspect of this set of problems: the role of the state in the structural transformation of capitalism and thus also in the structural transformation of the media industry as a subarea of the capitalist economy. I start from the assumption that the state is acting mainly - that is not exclusively —as agent, i.e. service provider for capital in the existential interest of capital, which lies also in the state's own existential self-interest.

Partly the state provides its services-so the further assumption-"by order" of capital ("under pressure" of capital's interests and strategies). Generally the state however also delivers these services because it is in its vested self-interest to adopt the interests of corporate capital as its own. Thus, in my view the state is by no means a helpless, deplorable or despicable "beadle of capital", but an active interest-oriented service provider. As the state does not carry out its activities as secret "intelligence operations", there is no reason for assuming any "conspiracy theories". The "inconvenient" (and thus hardly career supporting) scholarly "unmasking" or "exposure" of the state as "capital's agent" is thus only necessary because the state, for reasons of legitimacy, likes to mask itself with a number of ideologies in order to camouflage its one-sided partiality, which from a democratic and socio-political perspective is hardly legitimised.

Fundamental for the present structural transformation of capitalism are privatisation policies as they have been adopted on the ideological basis of neoliberal economic theory and politics. The media and communication industry is particularly entangled in this "era or privatisation" (Murdock 1990) through processes of deregulation and liberalisation. According to Zeuner (1998), it is possible to distinguish three general-interwoven-levels of privatisation.

1. The privatisation of state capital, i.e. the transformation of enterprises that had either in part or in full been public property, into private property.

2. The privatisation of public services, i.e. the gradual privatisation of public enterprises in the realm of infrastructure, which until then, due to the social importance of the public goods they were providing, served as (mostly monopoly-) providers of public services.

3. The privatisation of the state, i.e. the (partial) privatisation of classical state functions (e.g. private security services, universities) and the subjection of state-run organisations under the norms of commercial business-principles (e.g. public administration, universities)

These comprehensive privatisation policies mark capitalism's fundamental structural transformation: They present a radical shift from mixed economies, that until recently prevailed in Western Europe, to an almost exclusively privately organised economy. Even social democrats and unions are supporting or implementing these policies although (or precisely because?) originally it was the exact opposite, when they argued for the abolition of the private

\footnotetext{
24 I am aware that many will object to using the term "captial's agent" for the role of the state because it seems associated with unjustified conspiracy theories. I thus have added a question mark to the title. Nevertheless I regard the notion "capital's agent" in the sense of a service-providing agency as realistic approach for academically relevant questions.
} 
property of the means of production. This demand "belonged to the classical programmatic core of socialism and the worker's movement, not just in communist, but also social democratic sections" (Zeuner 1998, 286). The German Social Democratic (SPD) Party's 1959 Godesberger Programme that was valid until 1989 thus included the necessity of the partial public property of the means of production.

The media industry is involved at all three levels of privatisation policies that were mentioned above and partly even plays a pioneering role. The privatisation of telecommunications infrastructure and public broadcasting stations (as it happened in France) is an example of both the privatisation of state capital and the privatisation of public services. The admission of private broadcasting providers to the market is another example of the privatisation of public services. The marketisation and commercialisation of public broadcasting illustrates a case of the privatisation of the state. This also means that media capital and media-external capital that operate in these sectors of the media industry, profit at least in the long run from this multi-level-privatisation and thus contribute significantly to capitalism's general structural transformation (see Teuteberg 1998; Deutscher Bundestag 1998).

\subsection{State-led Regulation Policies and Capital's Self-regulation}

The relation between state and capital generally is shaped by an economisation of politics ${ }^{25}$ with close interrelations between politics and economics. The political system orients itself on economic "constraints" imposed by capital, particularly in regard to technological and economic competitiveness on global markets. In this context measures of deregulation and (re)regulation are especially significant. Three overlapping development phases can be regularly observed:

- First phase: Deregulation promoted by the state through creating legal frameworks (if necessary even by means of changing basic constitutional law) for the privatisation of national and public enterprises and for the "liberation" of capital from laws and regulations that capital regards as illegitimate constraint of its economic freedoms and thus brands as "bureaucratisation" or as "harmful for the market economy".

- Second phase: Self-regulation of industries, mostly driven by large corporations by means of market behaviour that constrains competition with the aim of achieving market domination.

- Third phase: (Re-)regulation through the state, again by creating legal frameworks and targeted support measures that aim at protecting and legitimising conditions of valorisation of the market-dominating capital.

In this process, the common assumption that public regulation could help to regain control over once privatised sectors or ensure that privately organised media products serve the public interest, largely proves to be an illusion. The realm of German television for example illustrates the paradoxical situation, in which a range of costly publicly funded regional media offices are exerting indirect, ineffective and largely unsuccessful control over private media companies. Regulating public broadcasting companies would offer a much more effective direct possibility for regulation.

How serious the state takes its role as agent for media capital is demonstrated by the fact that it generally only becomes active after a time lag and in a reactive manner without conceptual ideas (see Held and Schulz 1999, 116-117). The state then tends to limit its intervention to providing retrospective legitimacy for a reality already created by capital or integrating the newly established facts into an advantageous regulatory framework (see Knoche 1996b). Scholars have been propagating and legitimising this practice with terms such as "reflexive broadcasting laws", "contextual regulation", "soft regulation" and "regulation of selfregulation" (see Knoche 1999a; Recke 1998, 9ff).

\footnotetext{
${ }^{25}$ The following discussion is based partly on ideas developed in relevant previous publications (see Knoche 1996a und 1999a), which will be further advanced here.
} 
Form and content of the demanded or enacted measures of de- and (re-)regulation are a particularly suitable indicator for the respective relationship of the state and capital. It is therefore not surprising that within economic theory the identification of the role of the state in regard to regulation is subject to fundamental debate. Neither is it surprising that there exist as many economic regulation theories as there are general approaches to economic theory (or schools) (see Grisold 1996, 77ff). For my argument in this paper it seems fruitful to distinguish existing economic regulation theories according to how they treat the role of the state in relation to capital, or which normative roles they assign to both. Based on this perspective, the following approaches can be distinguished:

- According to the normative neoliberal theory, which regards regulation as a principally negative system-adverse "state intervention" into capital's individual (!) freedom that is only considered necessary in the exceptional case of "market failure", the state should refrain from regulatory measures.

- The simple Capture Theory of the Chicago School interestingly-and for me surprisingly close to reality-regards state regulation as "a means for the enforcement of the interests of the regulated" (Grisold 1996, 95).

- According to the extended Capture Theory the state as regulator also considers the interests of consumers as long as this seems politically opportune.

- The perspective of New Institutionalism and the Transaction-Cost Approach regards regulation as cost-effective and efficient and thus beneficial or even necessary for capital. Here, regulation is however not limited to state activities but can also take the form of contracts between companies.

- In Keynesian theory, state-led regulation is regarded as necessary in order to enable expedient corporate investment decisions and to ensure economic stability in the long run.

- The Marxist theory of State Monopoly Capitalism describes state-led regulation in the interest of and as a collaboration with private monopolies. It sees this state-capital nexus as an essential structural characteristic of capitalist economies.

- French Regulation Theory, which claims to be more than simply an economic theory of the capitalist mode of development, assigns the state a central role within a system of different regulatory bodies. Critics however stress that this theory lacks a more specific delineation of the state's role in capitalism (see Hirsch 1990, 27; Hübner 1990, 292ff).

The extended media and communication sector is one of the key economic industries. Therefore a theoretical approach that seems most appropriate for the analysis of the relation between state and capital is one that-in advancing and criticising the theory of state monopoly capitalism - focuses on the theory of state-monopoly complexes (see Michalski 1997, 29ff). Criticising and advancing this approach as Soviet capitalism scholars had originally developed it, a working group from Bremen (Dolata, Gottschalk, Huffschmid) described the development of state-monopoly complexes in close connection to the emergence of new needs necessary for the realisation of capital. The latter cannot be satisfied solely based on private capital flows. Due to high capital requirements, long-term capital fixation, high research expenses, long capital turnover times, and a correspondingly high investment risk, private production and capital realisation are not feasible in highly concentrated key industries, such as the media industry, unless aided by reliable and effective state support. On the basis of a stable institutional interlocking of state and centralised capital, the state thus on various levels provides a range of continuous financial and legitimatising services for media capital.

\subsection{State-Led Industrial Policies: The National Competitive State}

The state theorist Joachim Hirsch regards the establishment of a new type of capitalist state, which he calls the national competitive state, as a key characteristic of global capitalism's structural transformation (see Hirsch 1998, 33ff). The national competitive state's primary interest is, according to Hirsch, the optimisation of the conditions for capital realisation on a 
national level in competition with other nation states. Following this argument, the state's industrial and competition policies have increasingly become redistribution politics in favour of capital. This means that economic growth no longer leads to increasing mass welfare - as it was the case temporarily during the era of Fordism and Keynesian economic policy -, but instead results in mass unemployment, the dismantling the welfare state, and impoverishment of large parts of the population.

The national competitive state is a state that both passive and active. This means that it on the one hand does not interfere with the "free play of market forces". On the other hand it is (contrary to the dominant neoliberal ideology and clearly in the interest of capital) not at all a "weak" state ${ }^{26}$, but rather a strong, interventionist state. As such it actively enables and promotes-in intense co-ordination and consultation with large centralised corporationscapital's growth by means of privatisation, deregulation, infrastructure policies, industrial policies, regulatory policy, concentration-support policies (often state institutions and politicians use in this context the term "competition policy", although the actual outcome is more capital concentration!), tax and subsidy policies etc. The aim of these policies is to support the interests of corporate capital, its national market power and thus also its international competitiveness. In doing so, the direct co-ordination between top politicians and top managers or owners of large corporations replaces the state's controlling function, which however continues to be officially propagated.

The fact that the state privileges capital interest for the sake of economic prosperity, the capitalist mode of production and the existence of the state itself has become the subject of economic theory. Such political-economic approaches do not discuss such developments as completely new, but rather as a key characteristic of the relationship between state and capital. This relationship, in which the state assumes the role of capital's agent, already characterised the regulatory mode of Keynesian corporatism (see Hirsch/Roth 1986, 64ff), in which the representatives of capital and labour negotiate and make compromises, and continues to shape contemporary neoliberalism and related de-regulation policies (see Schui 1997; Reitzig/Brandl 1997). One duty of the state thus also is to protect the economic system from excessive demands (extra profits, monopoly rents) of individual corporations by guaranteeing a certain market order that has been created in the process of capital accumulation and centralisation (see Hirsch 1990, 46ff).

Since the private media industry is an integral part of capitalism, it consequentially follows that the discussed structural transformation of capitalism also applies to the media industry. This means that the state also acts as an agent of media capital and as such performs certain services for it (Figure 7).

\footnotetext{
${ }^{26}$ At the same time the state is an objectionable-and from a democratic perspective objectionable-a weak state inasmuch it is unable and unwilling to assert itself against the interest of capital, so that it largely refrains from interventions that aim at controlling corporate capital.
} 


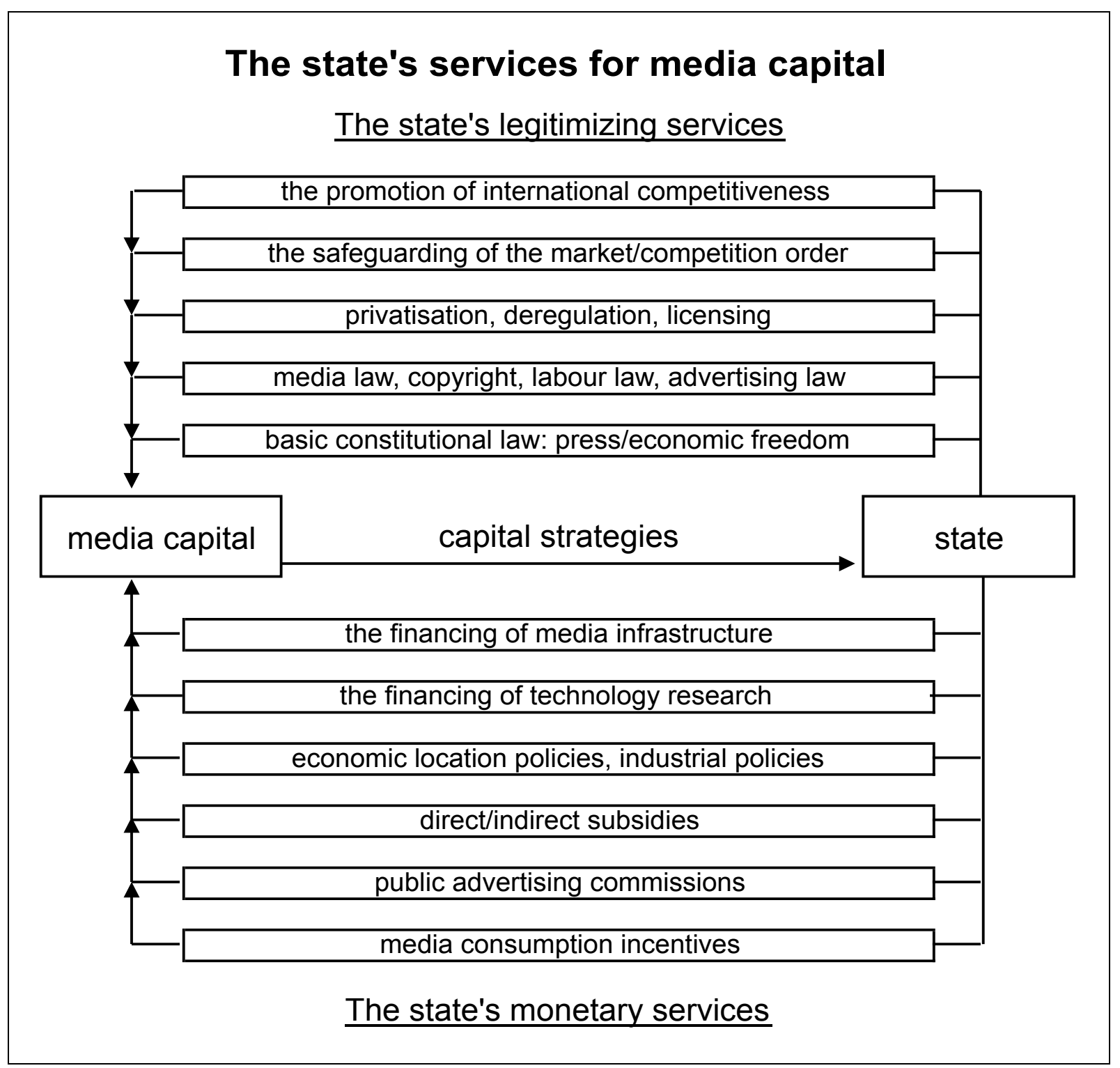

Figure 7: The state's services for media capital

Corporations often advance capital strategies by means of economic and political pressure (e.g. the threats of relocation or redundancies). Under the impact of such strategies, the state delivers both legitimizing and monetary services for capital. As part of the legitimizing services, the state guarantees economic and media-freedom through basic constitutional law ${ }^{27}$, media law, the protection of property- and copyrights, the protection of the relation of production between capital and labour through labour- and tariff-laws, the protection of frameworks for advertising through advertising-law etc. Furthermore, privatisation, de-regulation and the licensing of private media companies, and particularly the guarantee of the market- and competition-order as well as the (ideological) promotion of international competitiveness, are also part of the state's legitimizing services, even though these services indirectly also have a beneficial economic effect for capital accumulation.

In addition the state provides a number of direct monetary services for the media industry. They are delivered in the form of financial support of media infrastructure, technology, re-

\footnotetext{
${ }^{27}$ In the case of German Telecom (Deutsche Telekom), Germany even changed the basic constitutional law in order to provide a legal justification for the privatisation of state property.
} 
search and development ${ }^{28}$, direct and indirect subsidies, as part of economic location and industrial polices, as well as comprehensive public advertising commissions. Finally, the state through the education system as well as designated campaigns (e.g. the promotion of computer and Internet usage), creates incentives for media consumption. It is important to note that the state has a particular interest in adopting an agent role that is ideal for media capital because in return for its services it is expecting the media to contribute to the creation of popular mass-loyalty to the dominant economic and societal system.

Analysing capital as driver of the media industry's transformation and the state as capital's agent provides a number of lessons in media economics that could put media and communication studies scholars into a similarly difficult position as economics has long faced:

Economics can remain with consumer sovereignty (and state sovereignty, MK) and be comfortable, noncontroversial, increasingly sophisticated in its models and increasingly, and perhaps even dramatically, unrelated to life. Or it [economics] (and communication studies, MK) can accept the implications of producer power-of the sovereignty of the great organizations. Then it will be contentious, politically perilous and for a long while, perhaps, intellectually inelegant in its models. But it will in compensation be relevant to the most immediate and formidable concerns of the industrial society (Galbraith 1970, 478).

\section{References}

Abrahamson, David. 1998. The Visible Hand. Money, Markets, and Media Evolution. Journalism \& Mass Communication Quarterly 75 (1): 14-18.

Altmeppen, Klaus-Dieter. 1999. Arbeitsmarktentwicklung in Kommunikationsberufen. In Strukturwandel der Medienwirtschaft im Zeitalter digitaler Kommunikation, edited by Manfred Knoche and Gabriele Siegert, 69-87. München: Verlag Reinhard Fischer.

Altvater, Elmar. 1991. Die Zukunft des Marktes. Ein Essay über die Regulation von Geld und Natur nach dem Scheitern des "real existierenden" Sozialismus. Münster: Westfälisches Dampfboot.

Altvater, Elmar et al., eds. 1999. Turbo-Kapitalismus. Gesellschaft im Übergang ins 21. Jahrhundert. $2^{\text {nd }}$ edition. Hamburg: VSA.

Altvater, Elmar et al. 1999. Kapital.doc. Das Kapital (Bd.1) von Marx in Schaubildern mit Kommentaren. Münster: Westfälisches Dampfboot.

Artopé, Alexander and Axel Zerdick. 1995. Die Folgen der Media-Mergers in den USA. Die neue Ausgangssituation auf dem deutschen und europäischen Fernsehmarkt. Berlin/München: MGM.

Aufermann, Jörg, Bernd-Peter Lange and Axel Zerdick. 1973. Pressekonzentration in der BRD: Untersuchungsprobleme, Ursachen und Erscheinungsformen. In Gesellschaftliche Kommunikation und Information. Forschungsrichtungen und Problemstellungen. Ein Arbeitsbuch zur Massenkommunikation I, ed. Jörg Aufermann, Hans Bohrmann and Rolf Sülzer, 242-302. Frankfurt a.M.: Athenäum Fischer.

Aufermann, Jörg, Manfred Knoche, Bernd-Peter Lange and Axel Zerdick. 1976. AV-Medien-Bericht. Entwicklung der AV-Medien unter dem Aspekt intermediärer Konkurrenz und Konzentration auf nationaler und supranationaler Ebene. Gutachten für den Bundesminister des Innern. Berlin/Göttingen/Osnabrück (unpublished).

Bächlin, Peter. 1975. Der Film als Ware. Frankfurt a.M.: Athenäum Fischer.

Baubin, Thomas and Peter A. Bruck, eds. 1996. Strategische Entwicklungen für die Europäische Verlagsindustrie im Hinblick auf das Jahr 2000. Europas Multimedia-Herausforderung. Hauptbericht. Brussels/Luxembourg: European Commission.

Beckert, Bernd and Herbert Kubicek. 1999. Multimedia möglich machen: Vom Pilotprojekt zur Markteinführung. Ergebnisse und Schlußfolgerungen einer Synopse nationaler und internationaler Multimedia-Pilotprojekte. Media Perspektiven 3/1999: 128-143.

Bundesverband Deutscher Zeitungsverleger, ed. 1978. Kabelfernsehen und Bildschirmzeitung. Bonn: BDZV.

Deutscher Bundestag. 1998. Schlußbericht der Enquete-Kommission Zukunft der Medien in Wirtschaft und Gesellschaft-Deutschlands Weg in die Informationsgesellschaft zum Thema Deutschlands

\footnotetext{
${ }^{28}$ One example among many is the promotion of complex multi-media pilot-projects as market-entry projects for interactive television and on-demand video (see Beckert/Kubicek 1999).
} 
Weg in die Informationsgesellschaft. 13. Wahlperiode, Drucksache 13/11004. 22.06.1998. Bonn: Universitäts-Buchdruckerei.

Europäisches Medieninstitut. 1995. Bericht über die Entwicklung der Meinungsvielfalt und der Konzentration im privaten Rundfunk gemäß $\S 21$, Abs. 6, Staatsvertrag über den Rundfunk im vereinten Deutschland. In Die Sicherung der Meinungsvielfalt, ed. Die Landesmedienanstalten, 127-220. Berlin: Vistas.

European Communication Council Report. 1999. Die Internet-Ökonomie. Strategien für die digitale Wirtschaft. Berlin/Heidelberg/New York: Springer.

Fehrmann, Eberhard. 1999. Turbo-Kapitalismus. In Turbo-Kapitalismus. Gesellschaft im Übergang ins 21. Jahrhundert, edited Elmar Altvater et al., 7-15. $2^{\text {nd }}$ edition. Hamburg: VSA.

Galbraith, John Kenneth. 1970. Economics as a System of Belief. The American Economic Review 60 (2): 469-478.

Garnham, Nicholas. 1995. Multimedia-Ökonomische, institutionelle und kulturelle Konvergenzhindernisse. In Jahrbuch Telekommunikation und Gesellschaft 1995. Multimedia-Technik sucht Anwendung, edited by Herbert Kubicek et al., 70-77. Heidelberg: v. Decker.

Grisold, Andrea. 1996. Regulierungsreformen am Mediensektor. Der "Fall" Österreich. Frankfurt/Berlin/Bern/New York/Paris/Wien: Lang.

Hagen, Jörg. 1995. Wettbewerbsstrategien im europäischen Audiovisionsbereich. Wiesbaden: DUV.

Hagen, Lutz M. 1996. Die großen internationalen Medienkonzerne. In Markt-Macht-Medien. Publizistik im Spannungsfeld zwischen gesellschaftlicher Verantwortung und ökonomischen Zielen, edited by Claudia Mast, 119-132. Konstanz: UVK Medien.

Heinrich, Michael and Dirk Messner, eds. 1998. Globalisierung und Perspektiven linker Politik. Festschrift für Elmar Altvater zum 60. Geburtstag. Münster: Westfälisches Dampfboot.

Held, Thorsten and Wolfgang Schulz. 1999. Überblick über die Gesetzgebung für elektronische Medien von 1994 bis 1998: Aufbau auf bestehenden Regelungsstrukturen. Rundfunk und Fernsehen 47: 78-117.

Hertz, Markus. 1999. Music on demand: Chance oder Risiko für die Musikindustrie? Media Perspektiven 2/1999: 63-72.

Hirsch, Joachim. 1990. Kapitalismus ohne Alternative? Materialistische Gesellschaftstheorie und Möglichkeiten einer sozialistischen Politik heute. Hamburg: VSA.

Hirsch, Joachim. 1998. Vom Sicherheits- zum nationalen Wettbewerbsstaat. Berlin: ID Verlag.

Hirsch, Joachim and Roland Roth. 1986. Das neue Gesicht des Kapitalismus. Vom Fordismus zum Post-Fordismus. Hamburg: VSA.

Holzer, Horst. 1994. Medienkommunikation. Einführung in handlungs- und gesellschaftstheoretische Konzeptionen. Opladen: Westdeutscher Verlag.

Hübner, Kurt. 1990. Theorie der Regulation. Eine kritische Rekonstruktion eines neuen Ansatzes der Politischen Ökonomie. $2^{\text {nd }}$ edition. Berlin: Edition Sigma.

Huffschmid, Jörg .1970. Die Politik des Kapitals. Konzentration und Wirtschaftspolitik in der Bundesrepublik. $4^{\text {th }}$ edition. Frankfurt: Suhrkamp.

Jenner, Gero. 1999. Das Ende des Kapitalismus. Triumph oder Kollaps eines Wirtschaftssystems? Frankfurt a.M.: Fischer.

Jürgens, Ekkehardt. 1976. Neues vom Hörensehen. Zur Entwicklung neuer Audiovisions-Medien. In: Massen, Medien, Politik, edited by Wolfgang F. Haug, 5-72. Karlsruhe: Argument-Verlag.

Kiefer, Marie-Luise. 1998. Die ökonomischen Zwangsjacken der Kultur. Wirtschaftliche Bedingungen der Kulturproduktion und -distribution durch Massenmedien. In Medien-Kulturkommunikation, edited by Ulrich Saxer, 97-114. Opladen: Westdeutscher Verlag.

Klages, Johanna and Peter Strutynksi, eds. 1997. Kapitalismus am Ende des 20. Jahrhunderts. Hamburg: VSA.

Kleinsteuber, Hans J. and Barbara Thomaß. 1996. Konkurrenz versus Konzentration. Unternehmensverflechtungen im globalen Medienmarkt. In Internationale Kommunikation. Eine Einführung, edited by Miriam Meckel and Markus Kriener, 125-144. Opladen: Westdeutscher Verlag.

Knoche, Manfred. 1968. Kommentar und Kritik im Lokalteil der Tagespresse in der Bundesrepublik Deutschland. Eine pressestatistische und inhaltsanalytische Untersuchung. Publizistik 13: 348359.

Knoche, Manfred. 1981. Die Interessen der Zeitungsverleger an den neuen Kommunikationstechnologien. Informationen der LAG Massenkommunikation 1-2/1981: 29-35.

Knoche, Manfred. 1996a. Konzentrationsförderung statt Konzentrationskontrolle. Die Konkordanz von Medienpolitik und Medienwirtschaft. In Markt-Macht-Medien. Publizistik im Spannungsfeld 
zwischen gesellschaftlicher Verantwortung und ökonomischen Zielen, edited by Claudia Mast, 105-117. Konstanz: UVK Medien.

Knoche, Manfred. 1996b. Konzentrationsboom und Forschungsdefizite. Von der Presse- zur Medienkonzentrationsforschung. In Ökonomie der Medien und des Mediensystems. Grundlagen, Ergebnisse und Perspektiven medienökonomischer Forschung, edited by Klaus-Dieter Altmeppen, 101-120. Opladen: Westdeutscher Verlag.

Knoche, Manfred. 1997. Medienkonzentration und publizistische Vielfalt. Legitimationsgrenzen des privatwirtschaftlichen Mediensystems. In: Renger, Rudi/Siegert, Gabriele (Hg.). Kommunikationswelten. Wissenschaftliche Perspektiven zur Medien- und Informationsgesellschaft, edited by Rudi Renger and Gabriele Siegert, 123-158. Innsbruck/Wien: StudienVerlag.

Knoche, Manfred. 1999a. Zum Verhältnis von Medienpolitik und Medienökonomie in der globalen Informationsgesellschaft. In Globalisierung der Medien? Medienpolitik in der Informationsgesellschaft, edited by Patrick Donges, Otfried Jarren and Heribert Schatz, 89-106. Opladen/Wiesbaden: Westdeutscher Verlag.

Knoche, Manfred. 1999b. Strukturwandel der Öffentlichkeit nach dem Konzentrationsprinzip. In Massenmedien und Zeitgeschichte, edited by Jürgen Wilke, 731-745. Konstanz: UVK Medien.

Knoche, Manfred. 1999c. Medienjournalismus als Zirkulationsmittel des Medienkapitals. Zur medienökonomischen Funktion der Medienthematisierung in Printmedien. In Die Zukunft der Kommunikation. Phänomene und theoretische Ansätze einer innovativen Kommunikationswissenschaft, edited by Michael Latzer et al., 129-146. Innsbruck/Wien: StudienVerlag.

Knoche, Manfred. 1999d. Media Economics as a Subdiscipline of Communication Science. In The German Communication Yearbook, edited by Hans-Bernd Brosius and Christina Holtz-Bacha, 69100, Cresskill, NJ: Hampton Press.

Knoche, Manfred. 2014. Befreiung von kapitalistischen Geschäftsmodellen: Entkapitalisierung von Journalismus und Kommunikationswissenschaft aus Sicht einer Kritik der politischen Ökonomie der Medien. In Journalismus ist kein Geschäftsmodell: Aktuelle Studien zur Ökonomie und NichtÖkonomie des Journalismus, edited by Frank Lobigs and Gerret von Nordheim, 241-266. BadenBaden: Nomos.

Kohlstedt, Alexander, Peter Seeger and Runar Woldt. 1996/97. Europäische Medienkonzentration und strategische Allianzen im internationalen Multimedia-Markt. In Technisierung der Medien. Strukturwandel und Gestaltungsperspektiven, edited Bernd-Peter Lange and Peter Seeger, 165-191. Baden-Baden: Nomos.

Kordik, Hanna. 1999. Crash.com. Profil, No. 33 vom 16.8.1999: 52-57.

Latzer, Michael. 1997. Mediamatik—Die Konvergenz von Telekommunikation, Computer und Rundfunk. Opladen: Westdeutscher Verlag.

Luyken, Georg-Michael. 1990. Das Medienwirtschaftsgefüge der 90er Jahre. Horizontale und vertikale Unternehmensverflechtungen-Neue strategische Allianzen-Öffentliches Interesse. Media Perspektiven 10/1990: 621-641.

Meier, Werner A. and Josef Trappel. 1998. Media Concentration and the Public Interest. In Media Policy. Convergence, Concentration and Commerce, edited by Denis McQuail and Karen Siune, 38-59. London/Thousand Oaks/New Delhi: Sage.

Michalski, Hans-Jürgen. 1997. Der Telekommunikationskomplex. Politische Ökonomie der Technikund Infrastrukturentwicklung in der Telekommunikation. Marburg: BdWi Verlag.

Murdock, Graham. 1990. Redrawing the Map of the Communications Industries: Concentration and Ownership in the Era of Privatization. In Public Communication. The New Imperatives. Future Directions for Media Research, edited by Marjorie Ferguson, 1-15. London/Newbury Park/New Delhi: Sage.

Ouaj, Jamil, Penny Campbell, Runar Woldt and Joachim Wolframm. 1998. Digitales Fernsehen in Europa: Marktentwicklungen und Zugangsprobleme. Relation 5 (1): 73-82.

o. V. 1999. Popkomm: Angst vor Piraten im Internet macht kämpferisch. Salzburger Nachrichten, 23.8.1999: 15.

Recke, Martin. 1998. Medienpolitik im digitalen Zeitalter. Zur Regulierung der Medien und der Telekommunikation in Deutschland. Berlin: Vistas.

Reitzig, Jörg and Sebastian Brandl. 1997. Vom wohlfahrtsstaatlichen Grundkonsens zum "schlanken Staat". Die marktradikale Wendung der Gesellschaftsvertragstheorie. In Kapitalismus am Ende des 20. Jahrhunderts, ed. Johanna Klages and Peter Strutynski, 54-66. Hamburg: VSA.

Renner, Tim. 1999. "Der Generationswechsel muss her" (Spiegel-Gespräch). Der Spiegel 33/1999: 194-197. 
Rink, Jürgen. 1999. Die Geister, die ich rief. Chancen und Risiken der elektronischen Bücher. $c^{`} t$ 6/1999: 192-199.

Röper, Horst. 1997. Formationen deutscher Medienmultis 1996. Unternehmensentwicklung und Strategien der größten deutschen Medienkonzerne. Media Perspektiven 5/1997: 226-255.

Röper, Horst. 1999. Formationen deutscher Medienmultis. Entwicklungen und Strategien der größten deutschen Medienunternehmen. Media Perspektiven 7/1999: 345-378.

Rojas, Raúl. 1998. Über die globale Dynamik der Informationstechnologie. In Globalisierung und Perspektiven linker Politik. Festschrift für Elmar Altvater zum 60. Geburtstag, ed. Michale Heinrich and Dirk Messner, 194-205. Münster: Westfälisches Dampfboot.

Schrape, Klaus, Wolfang Seufert, Hansjörg Haas, Daniel Hürsta and Sabine Gafke. 1996. Künftige Entwicklung des Medien- und Kommunikationssektors in Deutschland. Berlin: Duncker \& Humblot.

Scheu, Andreas M. 2012. Adornos Erben in der Kommunikationswissenschaft. Eine Verdrängungsgeschichte? Köln: Herbert von Halem Verlag.

Schumacher, Werner. 1997. Deutschland digital. Wachstumsmarkt Telekommunikation. AnbieterProfile, strategische Allianzen, Personalnachfrage/Berufsbilder. Neuwied: Luchterhand.

Seufert, Wolfgang. 1997. Medienübergreifende Unternehmenskonzentration-Mittel zur Kostensenkung oder zur Erhöhung von Marktmacht? In Machtkonzentration in der Multimediagesellschaft? Beiträge zu einer Neubestimmung des Verhältnisses von politischer und medialer Macht, edited by Heribert Schatz, Otfried Jarren and Bettina Knaup, 258-273. Opladen: Westdeutscher Verlag.

Schui, Herbert. 1997. Die politische Ökonomie des Wohlfahrtsstaates und der Neoliberalismus. In Kapitalismus am Ende des 20. Jahrhunderts, edited by Johanna Klages and Peter Strutynski, 925. Hamburg: VSA.

Sjurts, Insa. 1998. Strategien der größten Medienkonzerne der Welt. In Internationales Handbuch für Hörfunk und Fernsehen 1998/99, edited by Hans-Bredow-Institut, 28-38. Baden-Baden/Hamburg: Nomos.

Teuteberg, Hans-Jürgen. 1998. Strukturmerkmale multimedialer Revolutionierung von Wirtschaft, Gesellschaft und Kultur an der Wende zum 21. Jahrhundert. In Vom Flügeltelegraphen zum Internet. Geschichte der modernen Telekommunikation, ed. Hans-Jürgen Teuteberg and Cornelius Neutsch, 294-409. Stuttgart: Franz Steiner.

Traufetter, Birgit R. 1999. Digitaler Videostandard DVD vor dem Durchbruch? Marktsituation im VHSVideosektor und Entwicklungen digitaler optischer Speichermedien. Media Perspektiven 2/1999: $50-62$.

Zeuner, Bodo. 1998. Das Politische wird immer privater. Zu neoliberaler Privatisierung und linker Hilflosigkeit. In Globalisierung und Perspektiven linker Politik. Festschrift für Elmar Altvater zum 60. Geburtstag, edited by Michael Heinrich and Dirk Messner, 284-300. Münster: Westfälisches Dampfboot..

\section{About the Author and the Translators}

\section{Manfred Knoche}

is professor emeritus for media economics at the University of Salzburg in Austria. He studied journalism/communication studies, sociology, political science and economics at the University of Mainz and the Free University of Berlin. He obtained his PhD (1978) and defended his habilitation (1981) at the Free University of Berlin. He was assistant and assistant professor for communications politics in Berlin in the years 1974-1983. From 1983-1994, he was professor of media and communication studies at the Vrije Universiteit Brussel in Belgium, where he was also the director of the Centre for Mass Communications Research. From 1994-2009 he held the chair professorship in media economics at the University of Salzburg in Austria, where he was Director of the Media Economics Group at the Department of Media and Communication Studies. He chaired the German Association for Media and Communication Studies' (DGPuK) media economics-section. He is author of many publications on the critique of the political economy of the media. His work has especially focused on the critique of the political economy of media concentration and the media industry's structural transformations. http://www.medienoekonomie.at, Twitter: @MedOek.

\section{Christian Fuchs}

is professor at, and the director of, the University of Westminster's Communication and Media Research Institute (CAMRI). He is co-editor of tripleC: Communication, Capitalism \& Critique. 
Marisol Sandoval

is a lecturer at City University London's Department of Sociology, where she is part of the Centre for Culture \& Creative Industries. She is co-editor of tripleC: Communication, Capitalism \& Critique. 